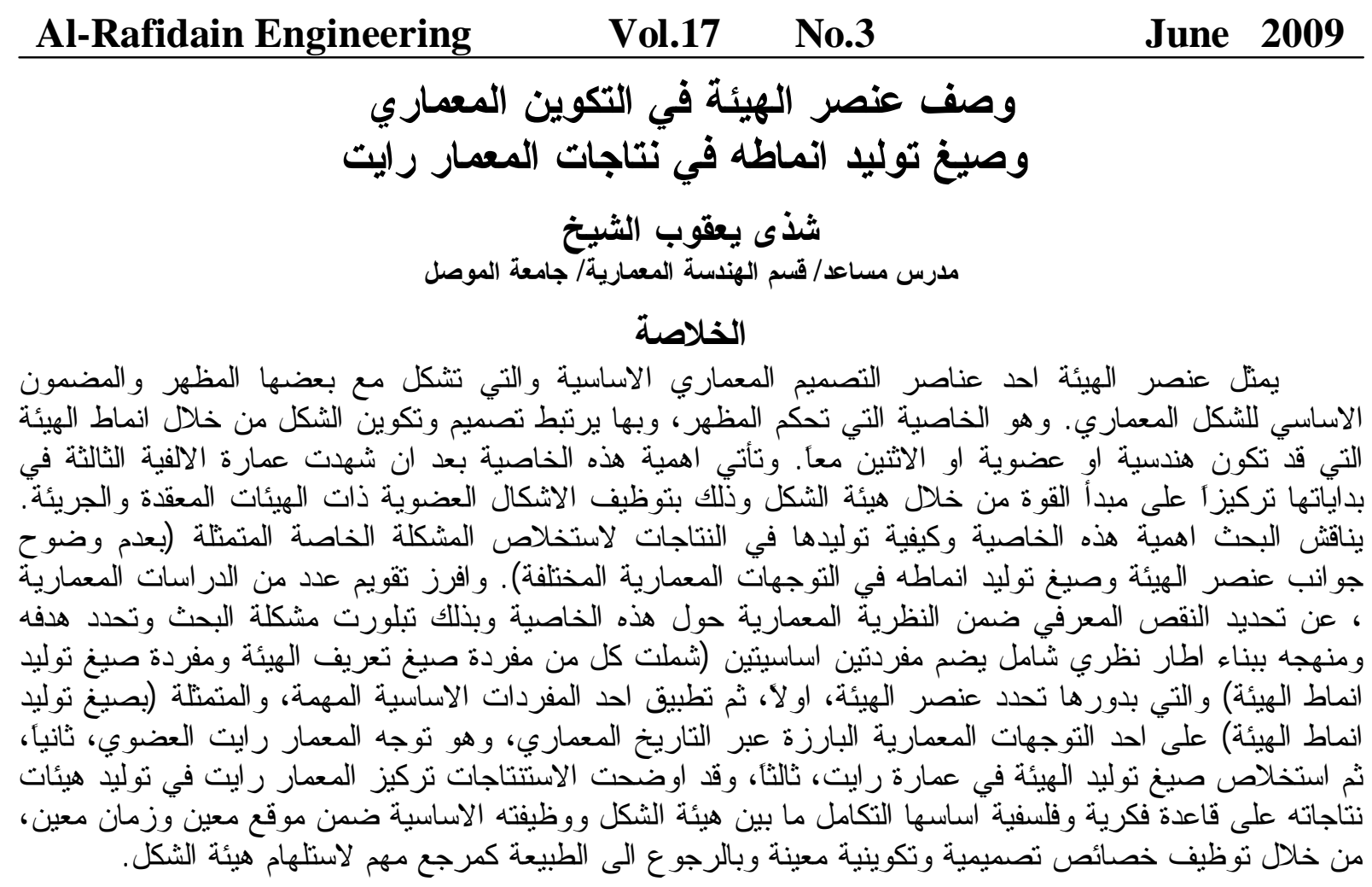

\title{
Description of shape element In Architectural composition Paradigms in creating shape types In Wright's works
}

\section{Shatha Yacoub Al Sheikh}

\begin{abstract}
Shape is presented as one of the architectural design's basic elements, which together determine the ultimate appearance and content of the architectural form. It is the property which determine the appearance, and for which the design and composition of form are related throughout shape types which might be geometric or organic or even the two as well. The importance of this property has emerged, especially, when the architecture of $21^{1 \mathrm{st}}$ century in its beginnings concentrated on the principle of "the power throughout shape" by using organic forms which have complicated and daring shapes. The paper discusses the importance of this property and its creation in the designs, in order to explore the particular problem which has been represented as (lack of clarity in description shape's element and paradigms of creating its types in different architectural trends).

Thus the objectives of the paper has been formed by building theoretical framework consisting of two main items of detailed theoretical field as the following: (paradigms of identification of shape and paradigms of creating shape types) which specifies shape element, firstly, then the application of the paradigms of creating shape types on one of the important trends throughout architectural history, which is Wright's organic trend, secondly, finally, concluding paradigms of creating form's shape in Wright's architecture, thirdly.

Conclusions have been declared Wright's concentration in creating shapes of its projects on a conceptual philosophy based on the integration between the shape and the main function of the building through selected place and time, by using selected design and compositional properties in relation to nature as a source of inspiration of form's shape.
\end{abstract}

Keywords: shape types, organic and geometrical shapes, Wright's archite 
1. 1 المقدمة// اهمية الموضوع

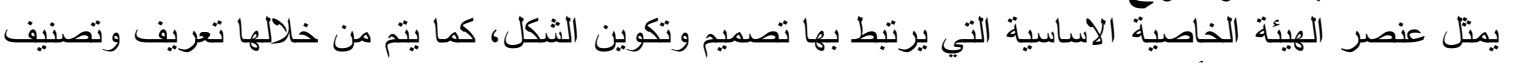

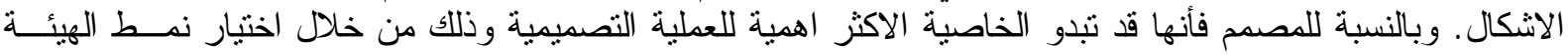

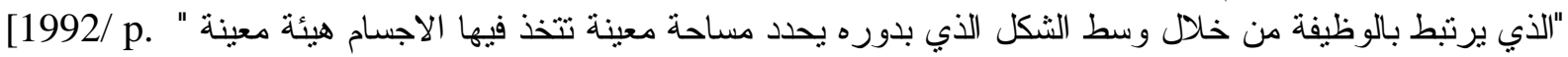

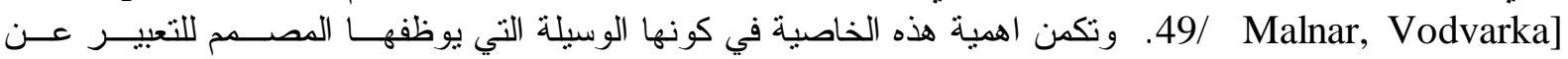

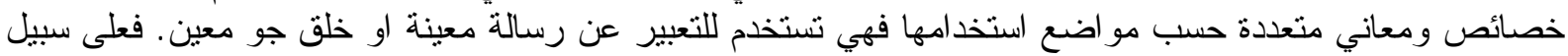

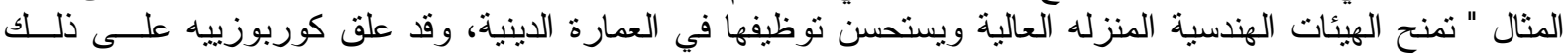

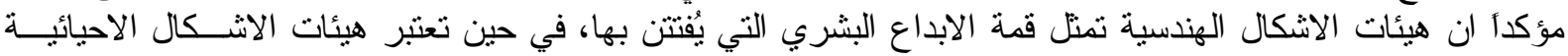

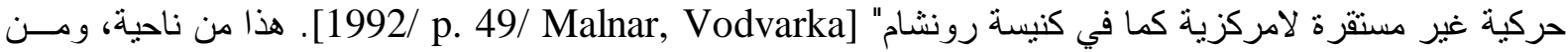

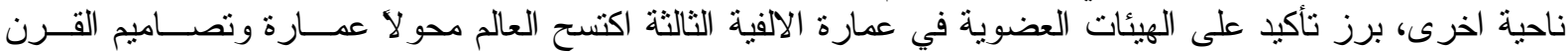

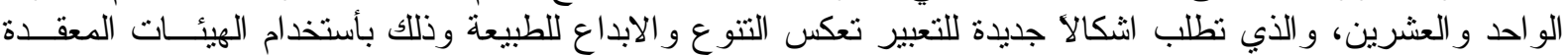

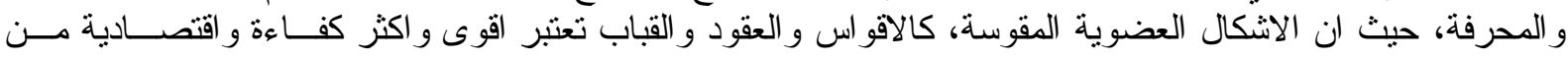

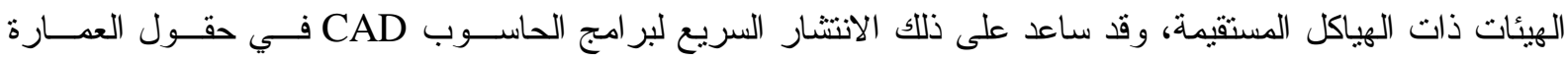

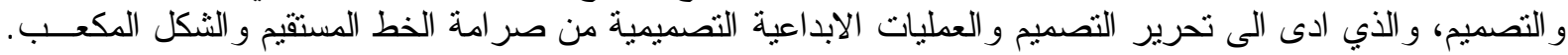

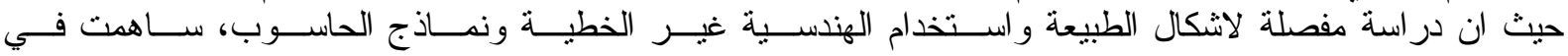

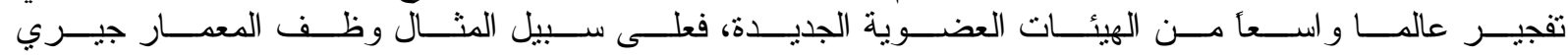

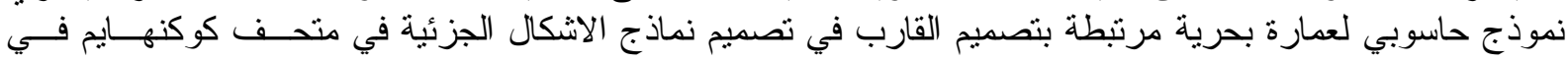
نه "Bilbao

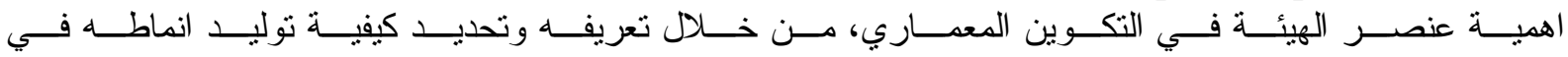

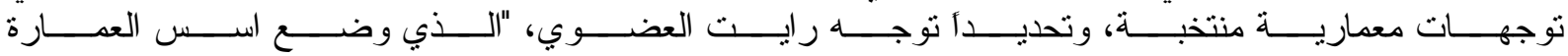

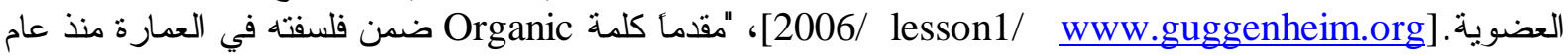

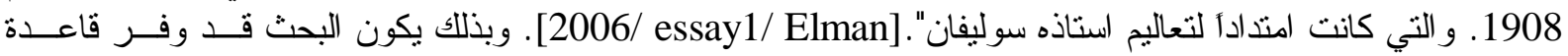
فكرية اساسية يمكن الاستفادة منها في توليد هيئة الثكل المعماري خلال العملية التصميمية.

\section{2. المشكلة الخاصة/ عنصر الهيئة في التكوين المعماري}

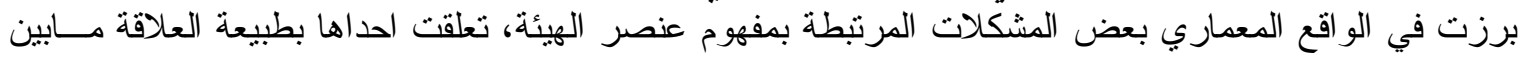

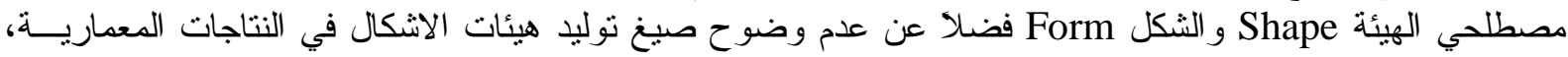

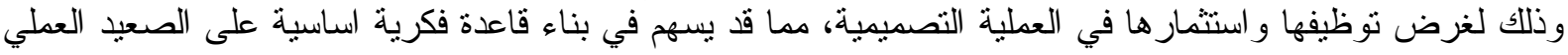

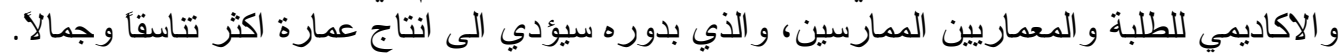

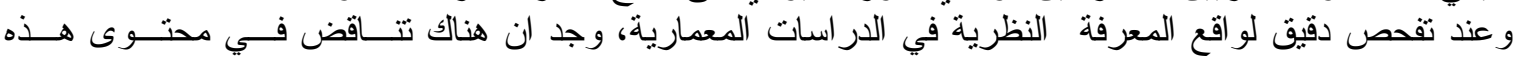

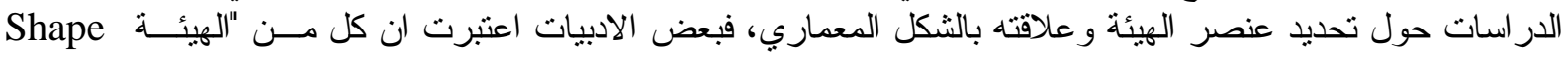

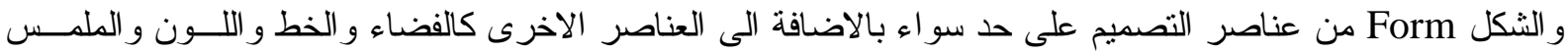

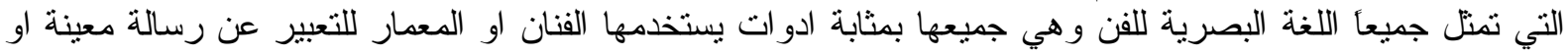

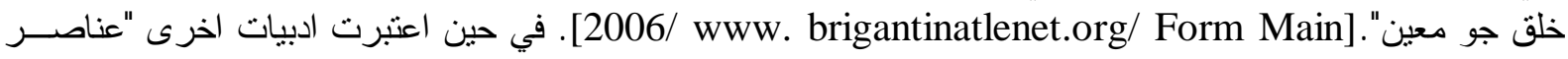

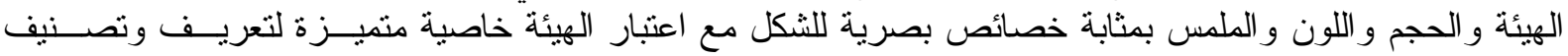

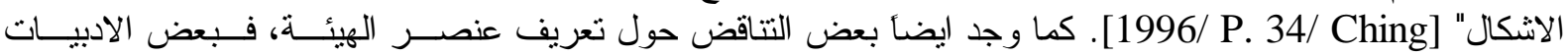

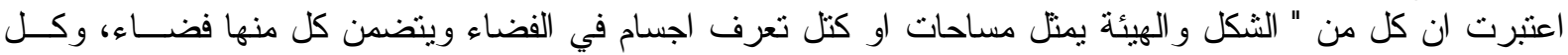

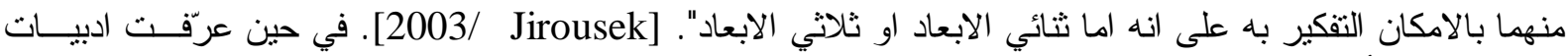

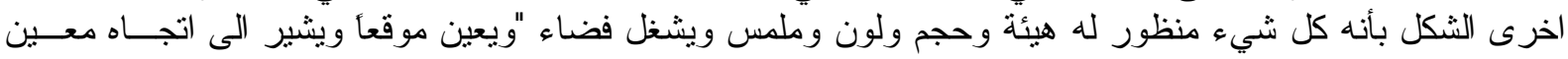

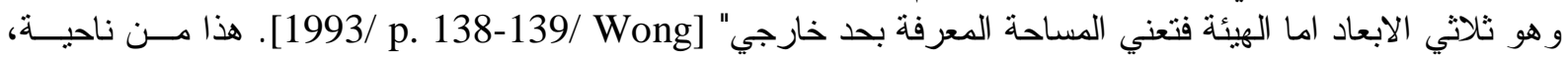

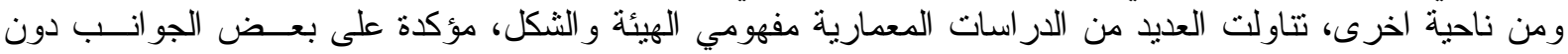

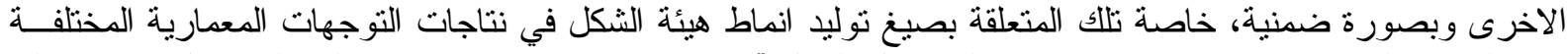

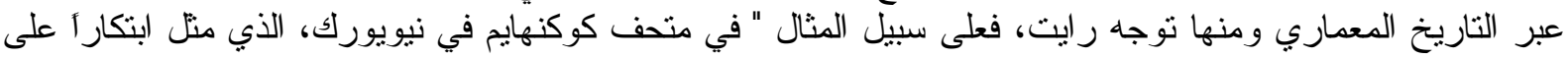

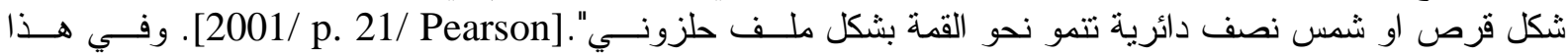

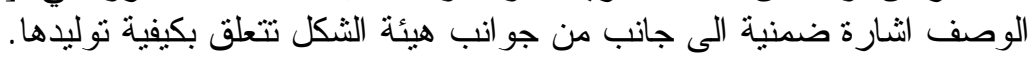


$\begin{array}{llll}\text { Al-Rafidain Engineering } & \text { Vol.17 } & \text { No.3 } & \text { June } 2009\end{array}$

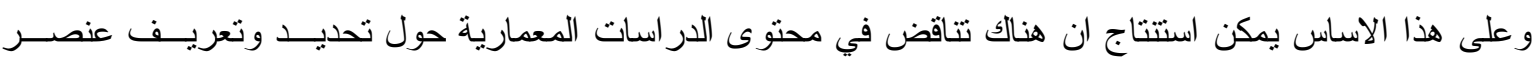

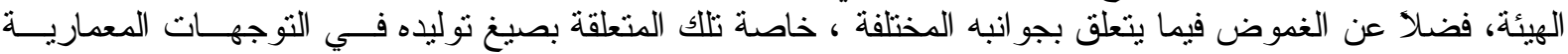

المخنلفة

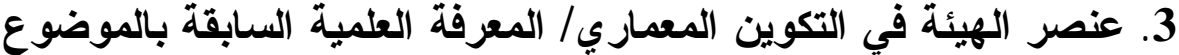

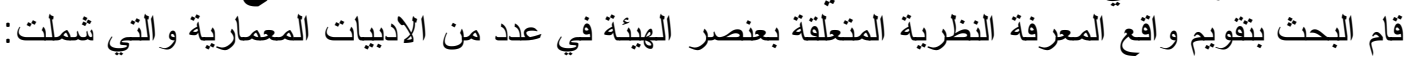

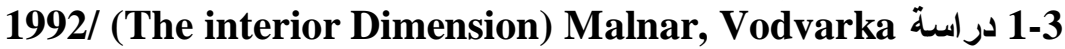

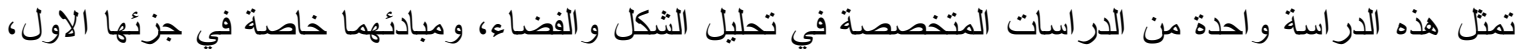

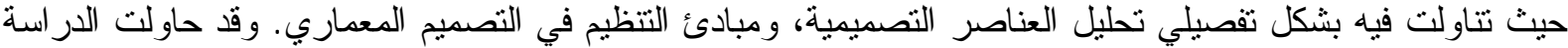

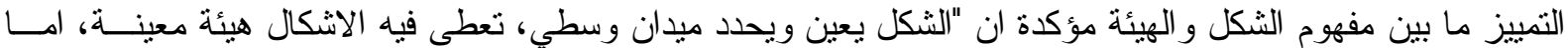

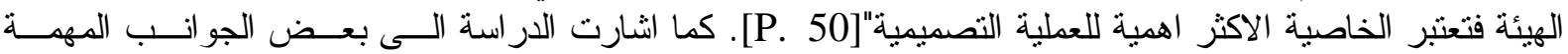

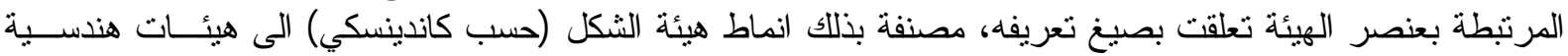

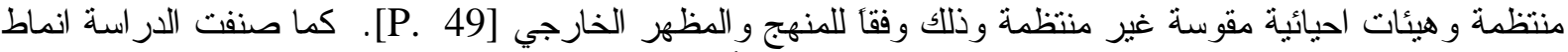

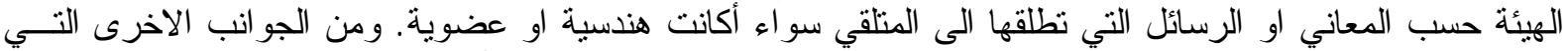

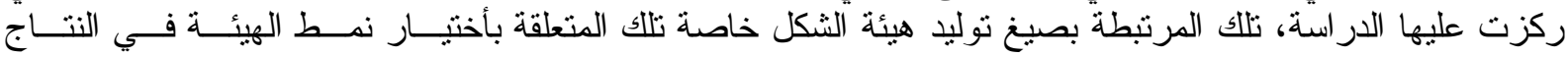

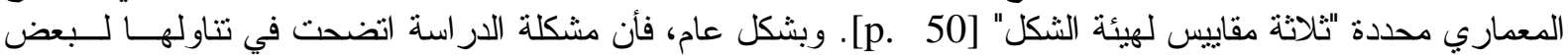

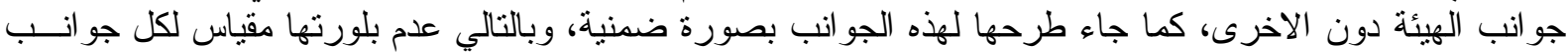
الهيئة وصيغ تحققها في النتاجات الخاصة بمعماريين مختلفين في توجهاتهم المعمارية.

1993/ (principles of Form and Design) Wong 2-3 در اسة (20)

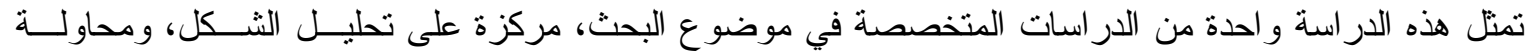

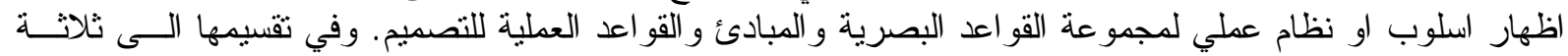

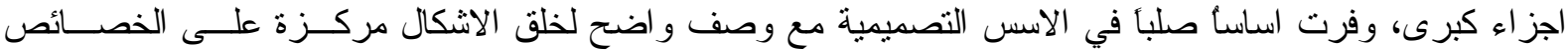

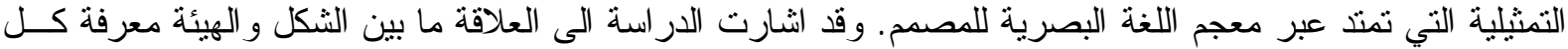

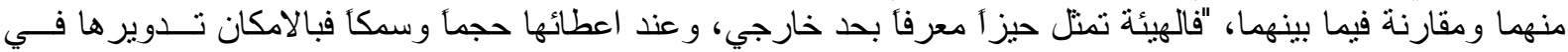

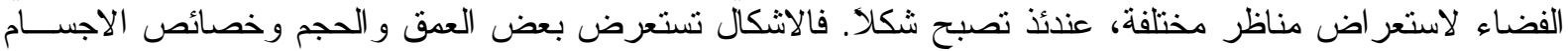

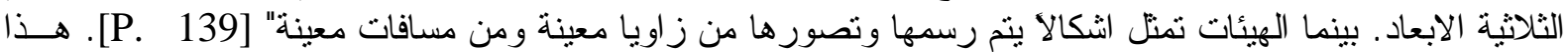

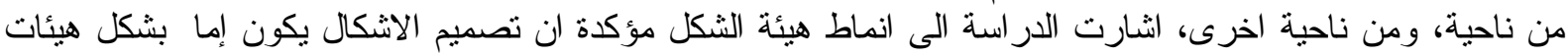

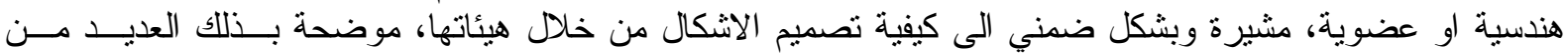

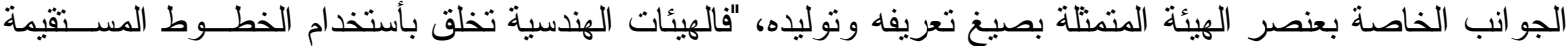

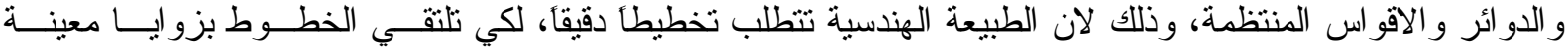

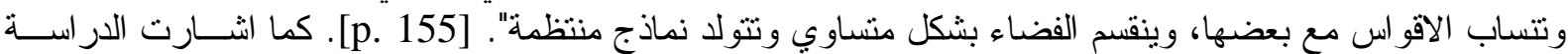

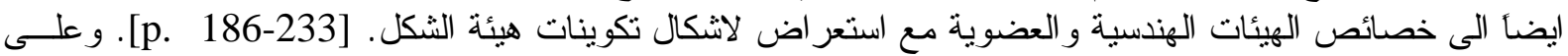

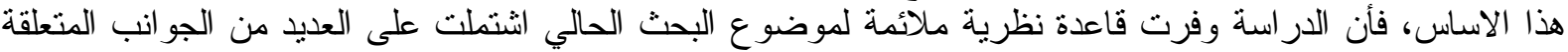

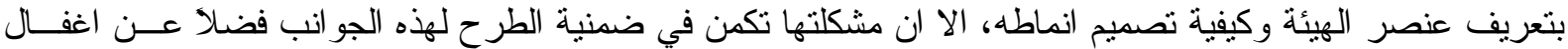

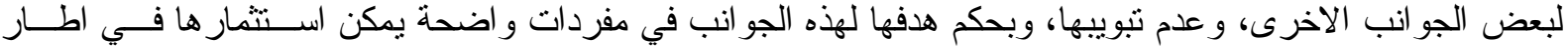
نظري شامل يصف الهيئة وكيفية تحققه في النتاجات المعمارية الخاصةً بمعماري معين.

1996/ (Architecture, Form, Space and Order) Ching 3-3 دراسة

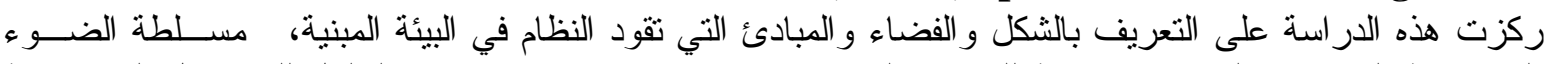

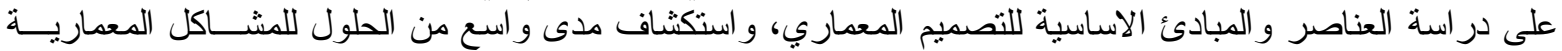

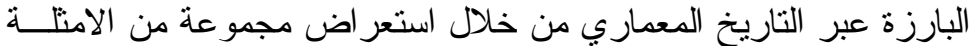
المصورة المختلفة في سياقاتها الزمانية و المكانية و الثشاملة للمضامين و المباديء الماءئ و الافكار الاساسية الثكلية و الفضــائية.

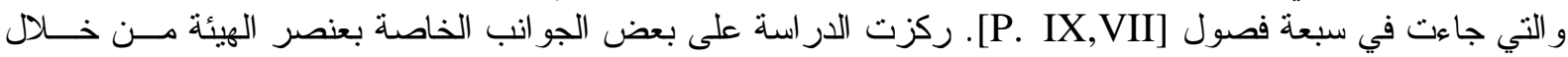

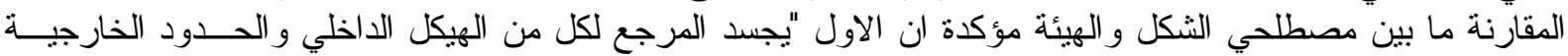

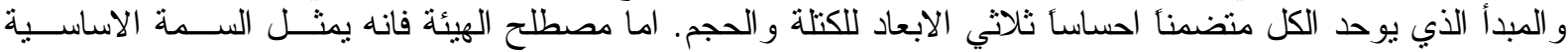

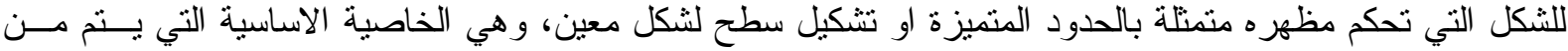

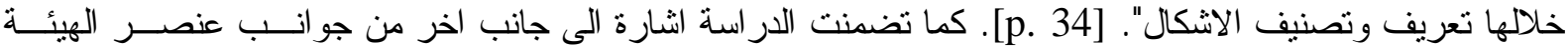


مرتبط بتعريفه من خلال تصنيف هيئات الاثكال وفقاً لحدودها الخارجية الى منتظمة وغير منتظمة كالهيئات الهندســية

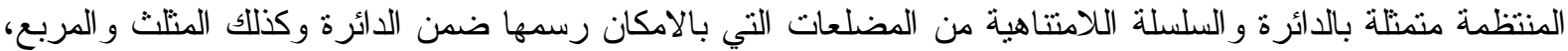

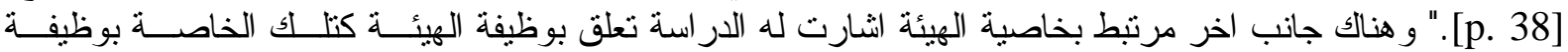

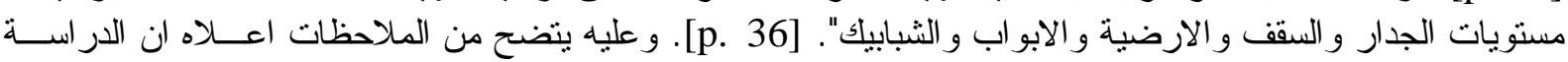

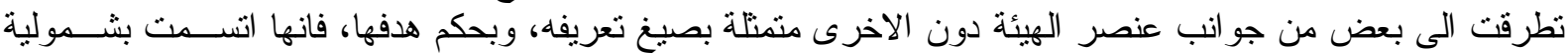

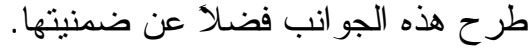

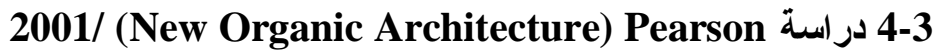

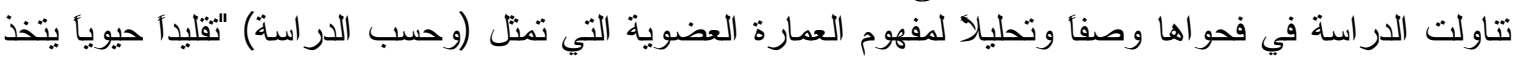

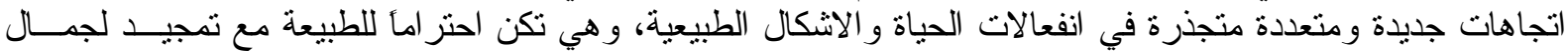

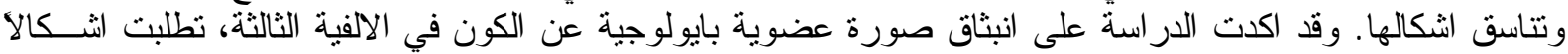

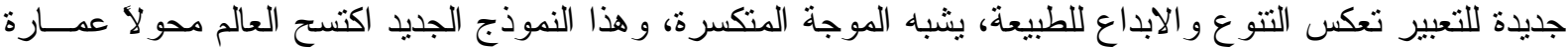

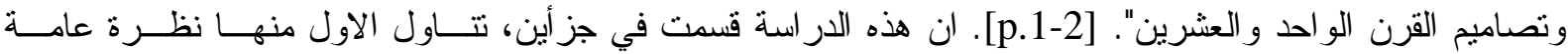

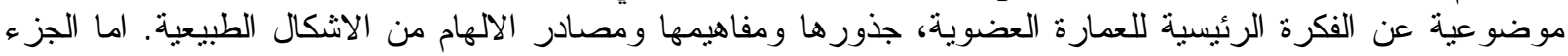

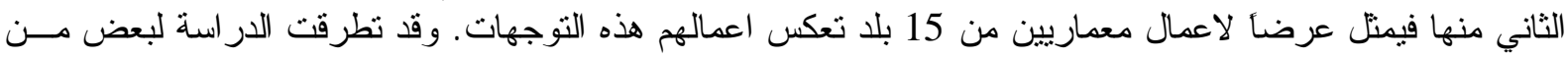

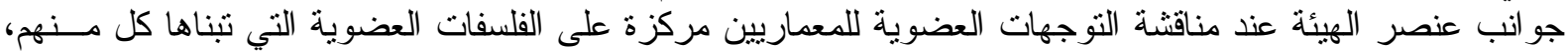

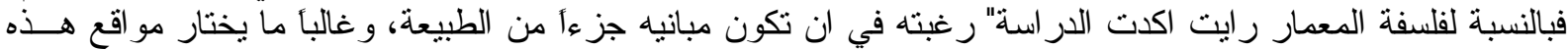

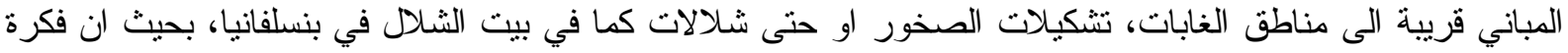

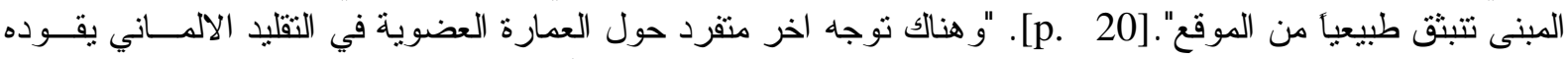
Rudolf Steiner

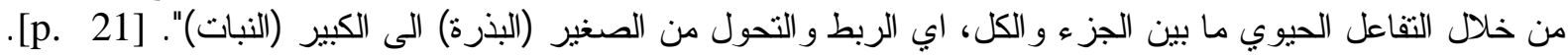

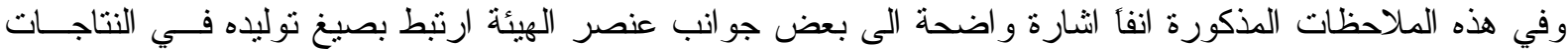

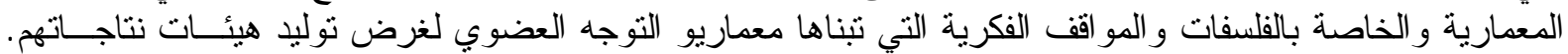

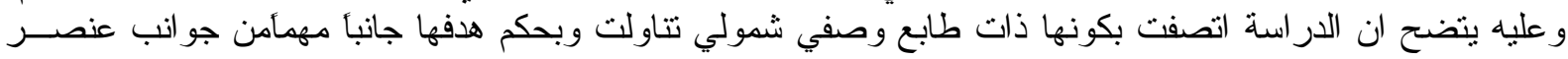

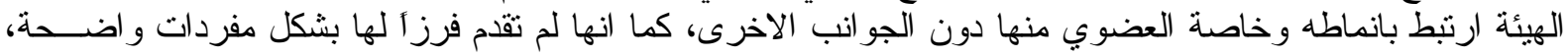

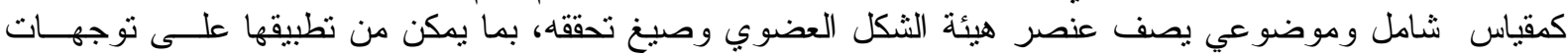

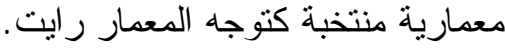
يُستنتج مما سبق اعلاه: ان الادبيات المعمارية التي تتاولت في محتو اها موضو ع البحث الحالي اتسمت بعدم قدرتها

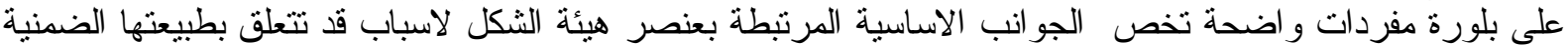

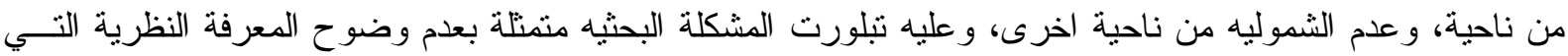

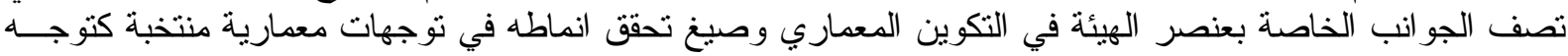

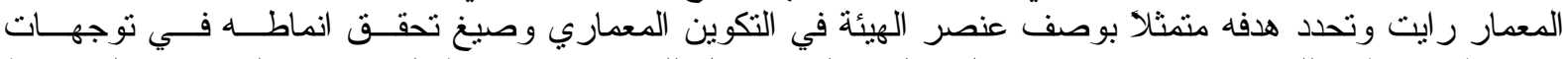

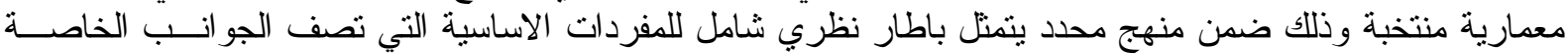

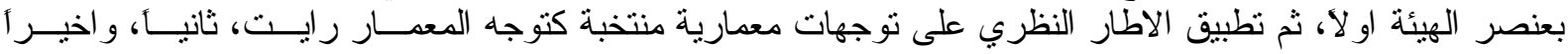
استخلاص صيغ تحقق انماط هيئة الثكل في نتاجات رايت، ثالثأ.

\section{4. الاطار النظري لعنصر هيئة الثكل في التكوين المعماري}

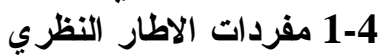

لقد تركز عنصر الهيئة حول جو انب مختلفة تم فرز ها من الدراسات السابقة، وقد ارتبطت هذه الجو انب بمفــردتين

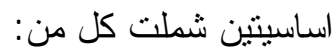

1 المفردة الاولى: صيغ تصنيف تعريف الهيئة 2. المفردة الثانية: صيغ خلق او توليخ الاولي الهيئة 1-1-4 المفردة الاولى: صيغ تعريف الهيئة

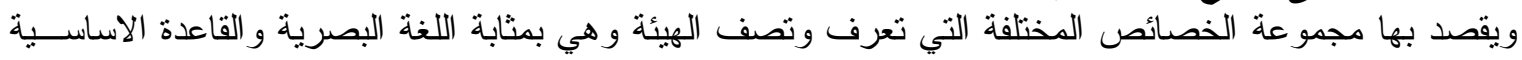

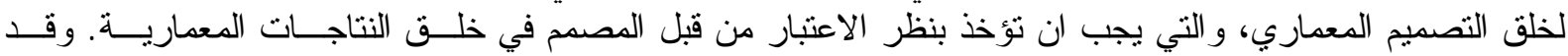

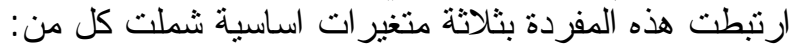
1. صيخ مرتبطة بخصائص بصرية. 


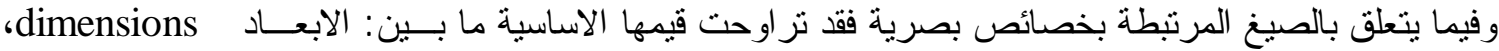

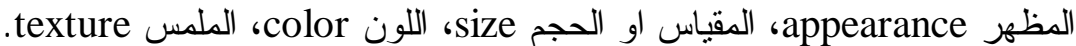
فيما يتعلق بخاصية الابعاد فقد ارتبطت بقيميتين ثانوينتين:

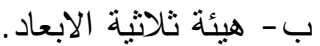
أ - أ هيئة ثنائية الابعاد.

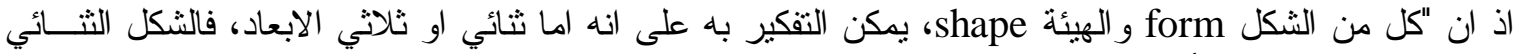

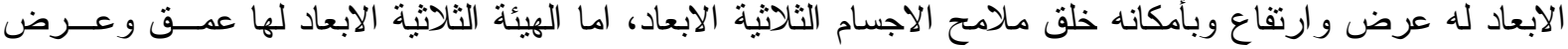

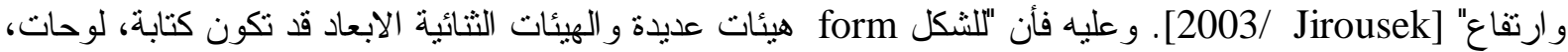

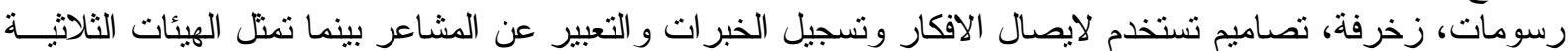

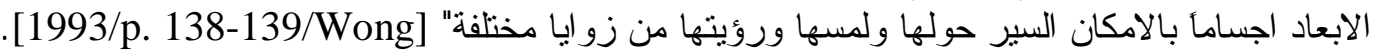

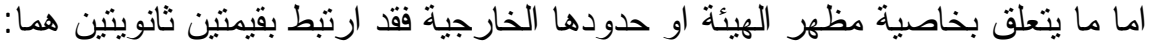

أ. هيئة هندسية وeometric و التي "تمنل وسيلة للتعبير عن المظهر معتمدة الخطوط المستقيمة و الاقو اس و الدوائر".

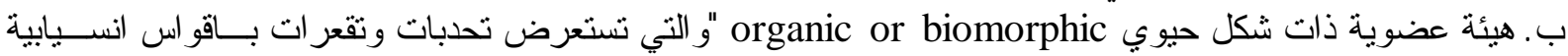

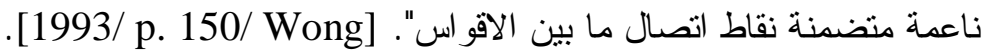
وفي السياق ذاته "جسد كاندينسكي تصنيفاً لانماط الهيئة الى هندسية نظامية وحيوية مقوسة بشكل غير نظامي، مؤكداً ان هذا التمييز بين الهندسة وعلم الاحياء مفيد في تحقيق اهداف تصميمية مرتبطة بــالمظهر الخرجية". /

.Malnar] ج. هيئة يدوية Calligraphic. "وتمثل احد الوسائل للتعبير عن المظهر يدويأ بأسلوب خط اليــد، فحركــة البـــــو واداة

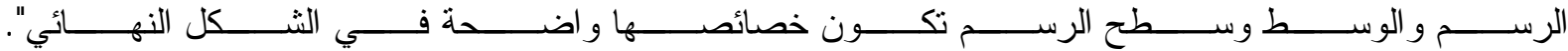
.[1993/ P.149/ Wong] اما فيما يتعلق بخاصية مقياس او حجم هيئة الثكل فقد شملت:

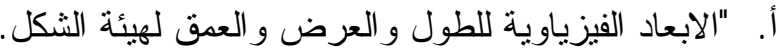
ب. نسب هيئة الثكل في علاقتها مع هيئات اخرى في سياقها و التي توصف بصيخ اكبــر و اصــغر". / .ching] اما فيما يتعلق بخاصية اللون فقد شملت كل من:

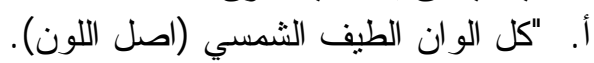

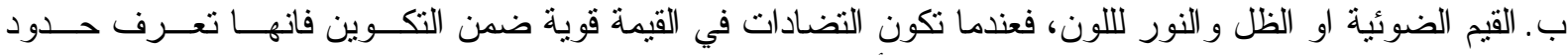

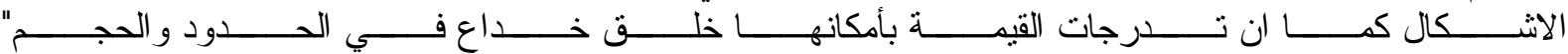
.[2003/ Jirousek]

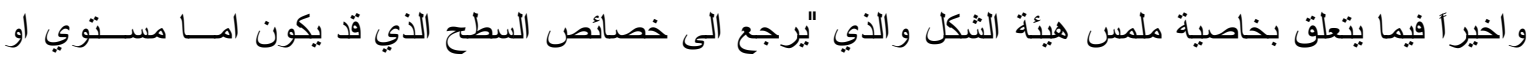

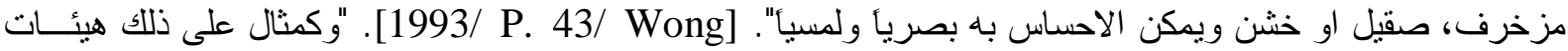

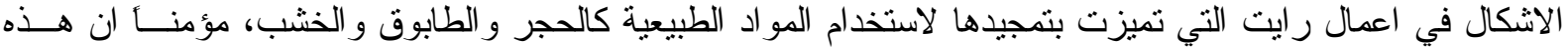

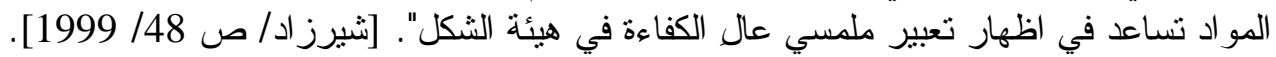

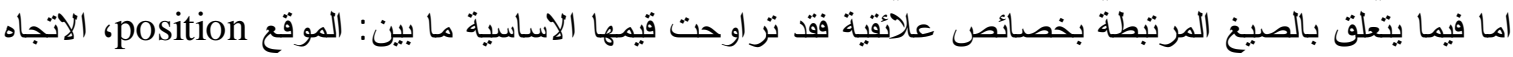
direction

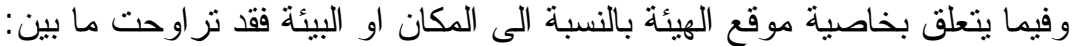

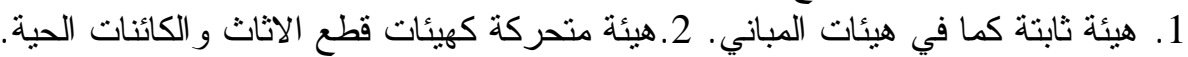

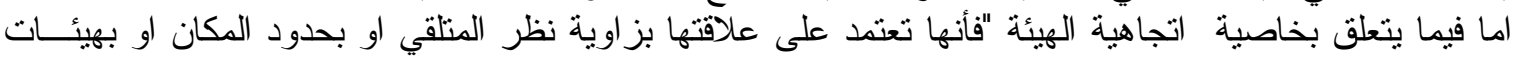

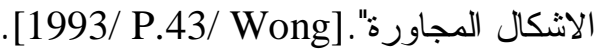

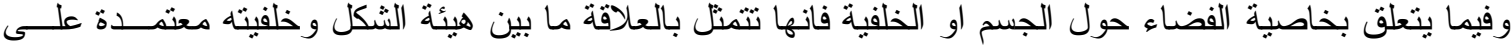

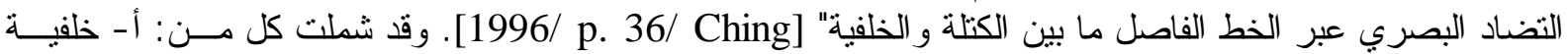

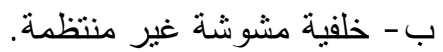

منتظمة.

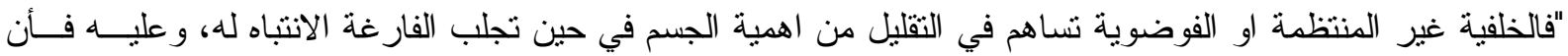

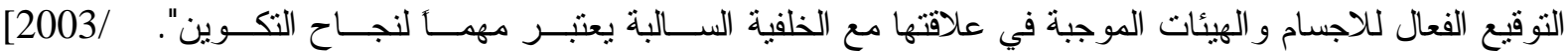




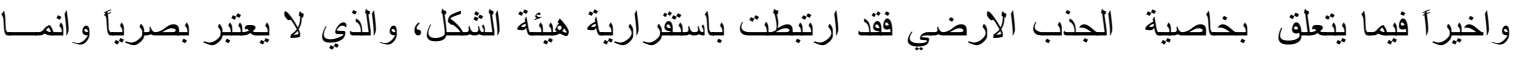

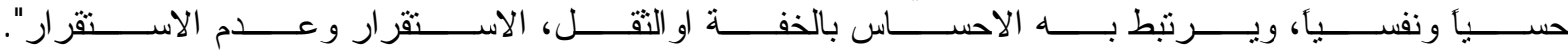

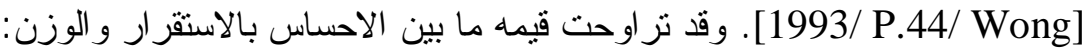
أ - هيئة مستقرة د - هيئة ثقيلة. ج - هيئة خفيفة.

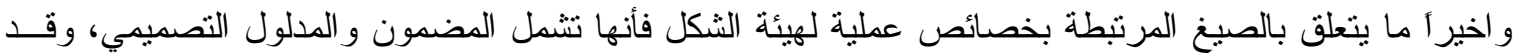

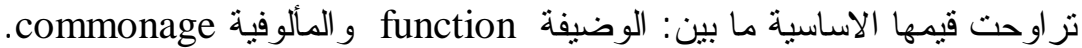
وفيما يتعلق بوظيفة الهيئة فقد تر اوحت قيمها الوضها الثانوية ما بين: أ - وظيفة نفعية و التي شملت:

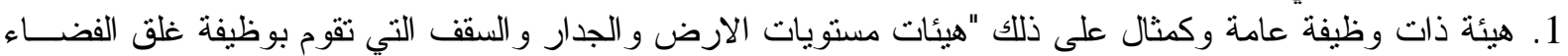

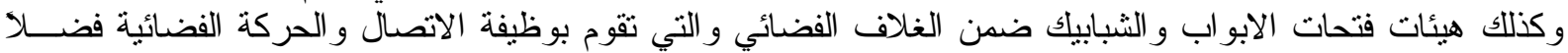

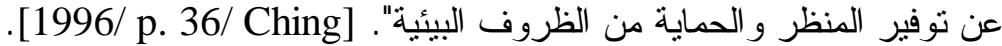

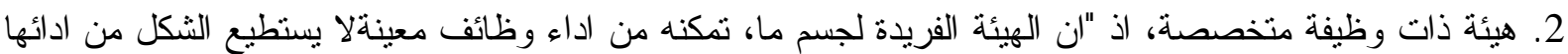

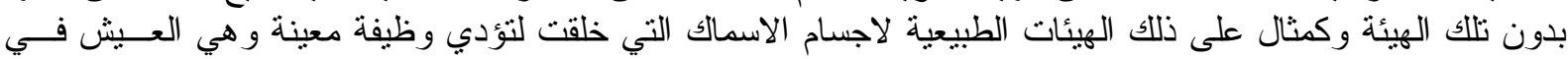

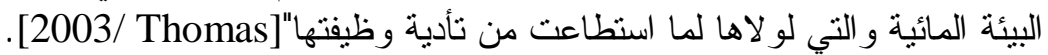
ب. وظيفة اتصالية و التي شملت: 1. هيئة تعبيرية تكون "معبرة عن فكرة او معنى ير اد وصفه فيها اضافة الى وظيفتهـا، [الزعبـــ/ ص 1978].

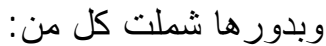

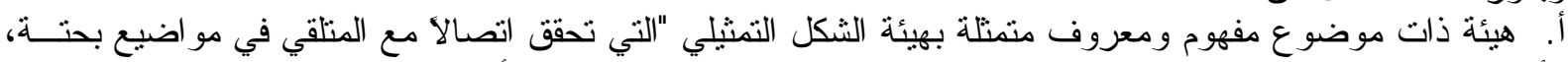

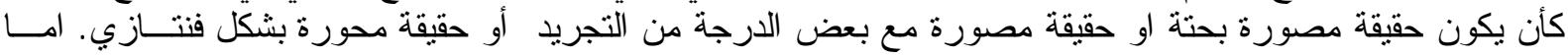

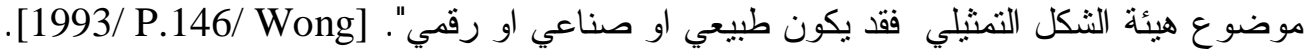

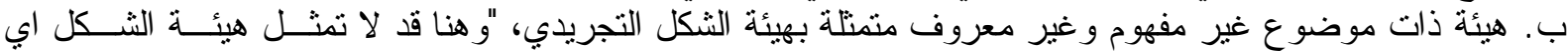

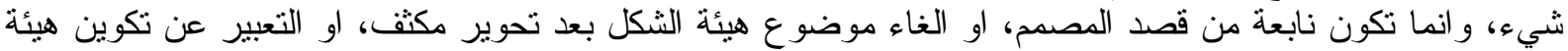

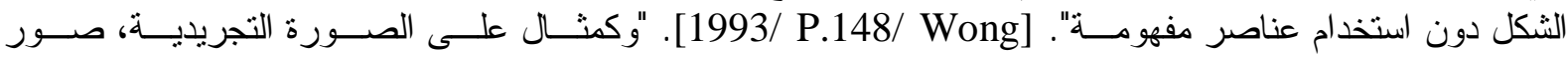

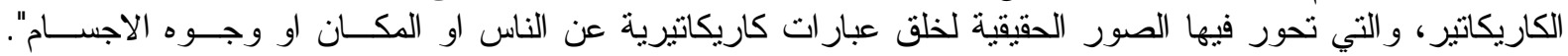
.[2003/ Jirousek]

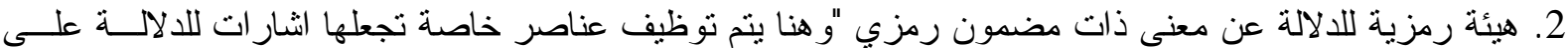

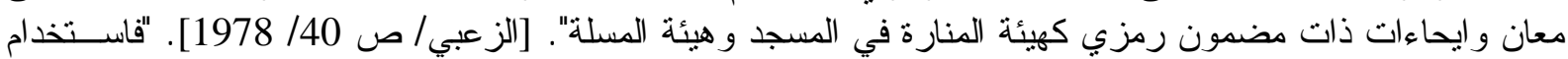

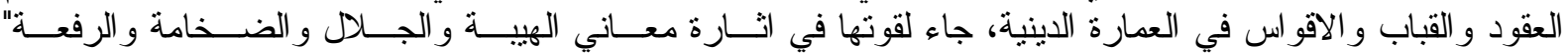
كرئ [2001/p.3/ pearson]

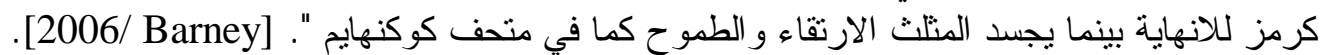

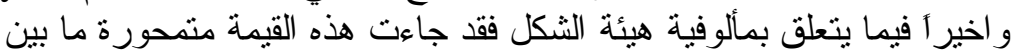

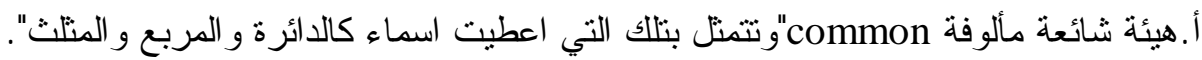
ب. هيئة متفردة بحد ذاتها ذات اشكال حرة. [2006/ Formmain]. يوضح جدول [4 - 1-3 المفردة الاولى داتى

4 - 4 - المفردة الثانية: صيغ تحقق او توليد او خلق انماط الهيئة:

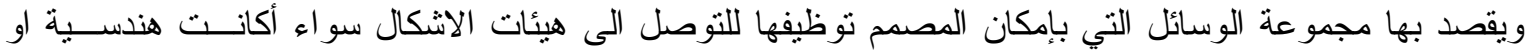

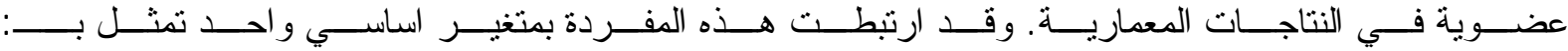
طبيعة صيغ تحقق انماط الهيئة وبدوره فقد ارتبط هذا المتغير بثلاثة متغير ات ثانوية شملت: أ. صيخ مرنبطة بمو اقف فكرية. ب.صيخ مرنبطة بخصائص الهيئة. ج.صيخ مرنبطة بالمر اجع. 
جلول [4-1]: القيم الممكنة للمفردة الاولى: صيغ تعريف الهيئة

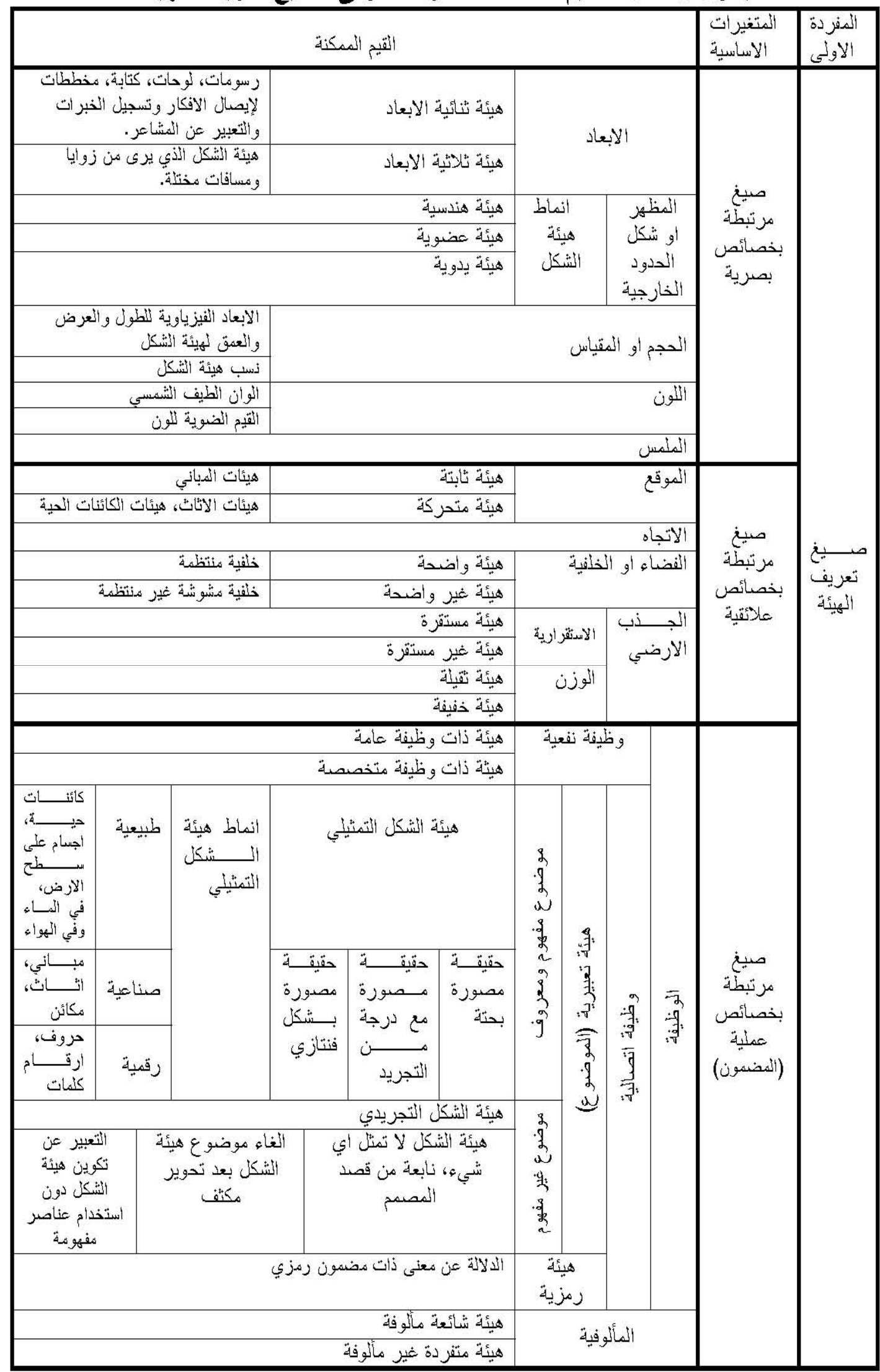




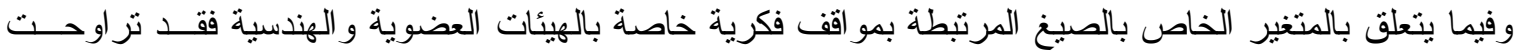

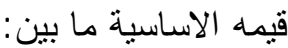

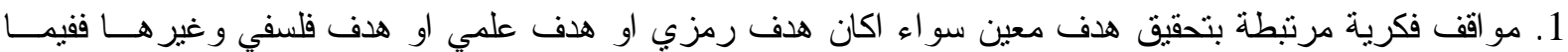

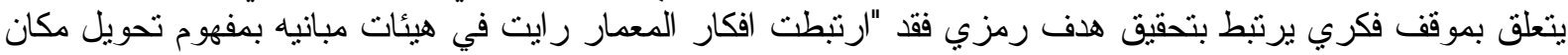

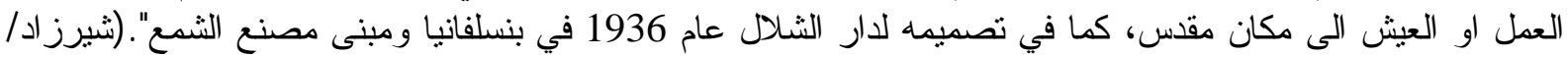

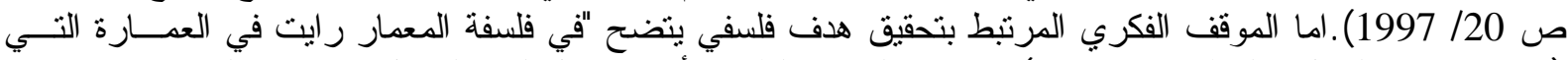

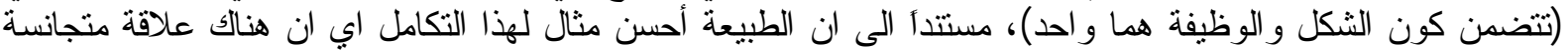

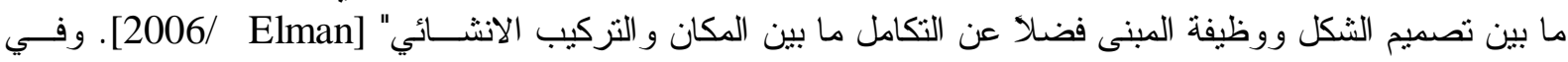

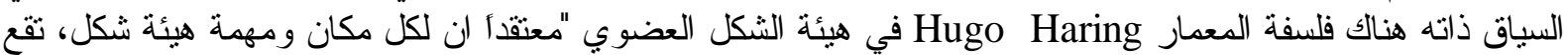

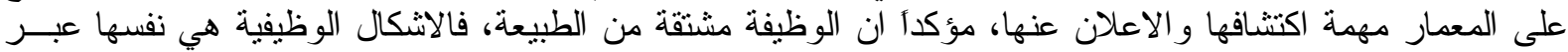

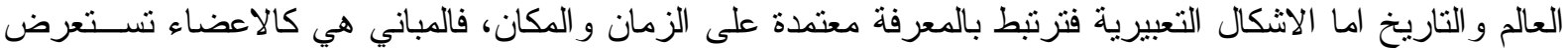
كائن حيوي هو الثكل" [2001/p.15/ Pearson]

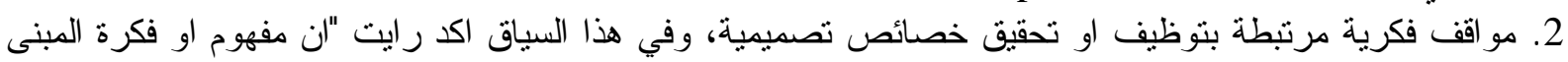

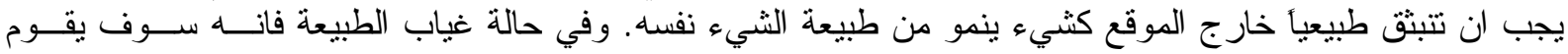

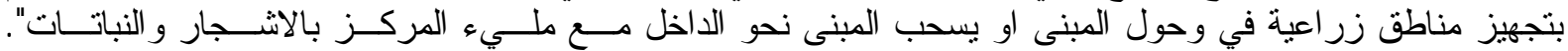
.[2001/p.15/ pearson]

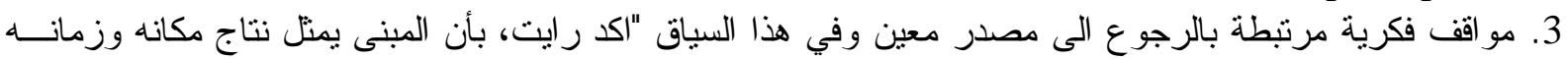

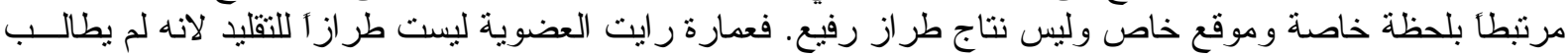

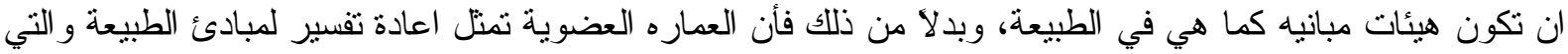

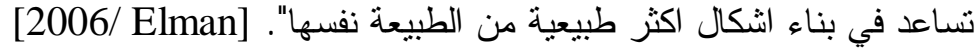

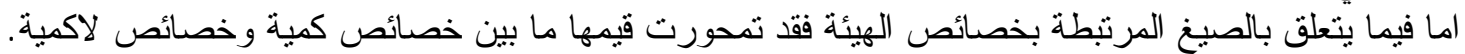

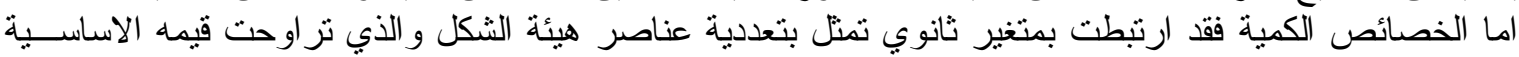

ما بين:

أ. هيئة الثكل المنفرد و المتمثلة "باحتو اء التكوين على شكل واحد فقط، ليس له اشكال متعددة متميزة اصغر" /1993] .p. 152/ Wong] ب. هيئة الثكل التجميعي و الذبي تر اوحت قيمه الثانوية ما بين:

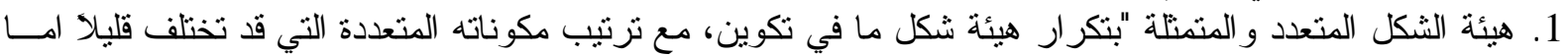

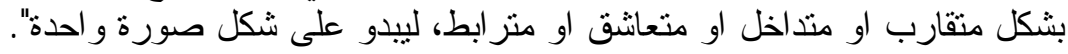
2. هيئة الشكل المركب و المتمنلة باتحاد الشكال مختلفة". 3. هيئة الشكل ذات الوحدة المتكررة و المتمنتة"بتكر ار هيئة شكل ما في تصميم معين، وهي تعتبر عناصــر مسـتقلة لا تشكل شكلا اكبر". 4. هيئة الشكل ذات الوحدة المفرطة و المتمثلة "بتجميع هيئات شكلين او أكثر ذات الوحدة المتكررة معأ ومن ثم تكر ارها

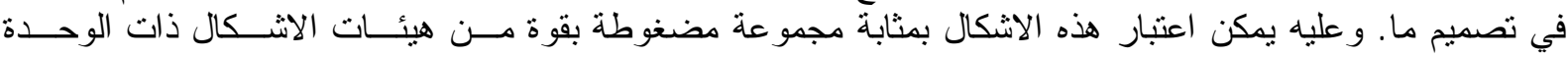

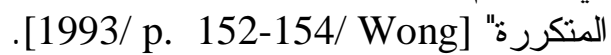

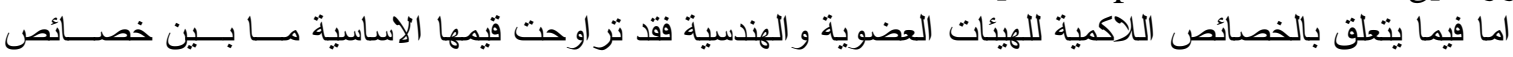
تصميمية وخصائص تكوينية.

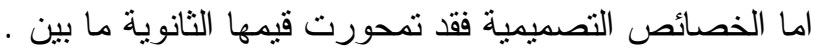
1. خصائص مظهرية (عناصر الخط و المستوي و الحجم) 2. خصائص جوهرية (علاقات او مبادئ).

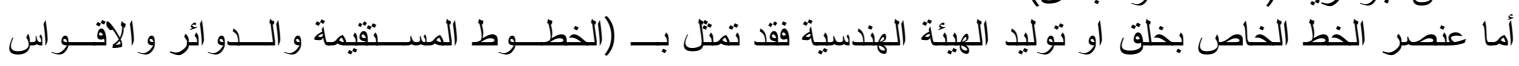

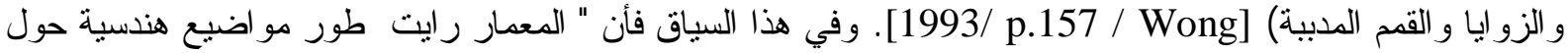

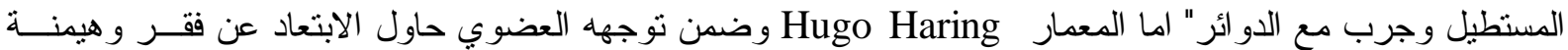

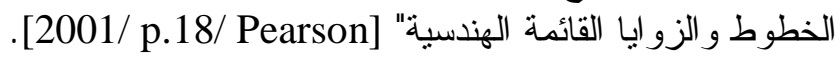
و هذه بدور ها تحكمها العلاقات و المبادئ العباديء التالية: 1. العلاقة ما بين الخطوط المستقيمة وتشمل: 
تغيير الموقع او الاتجاه، التلامس، الربط، التذاخل، ارتباط نهاية الى نهاية او نهاية الى حافة، توظيف الخطـــوط القويـــة (مخطط 1) 2. العلاقة ما بين الدوائر وتشمل: التلامس، الربط، التعاشق، توظيف دو ائر بخطوط عربضة، توظيف دوائر بحجوم مختلفة (مخطط 2).

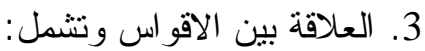
التلامس، الربط، التعاشق، التذاخل، توظيف نهايات و احجام مختلفة للاقو اس(مخطط 3) . 4. العلاقة بين الخطوط المستقيمة و الاقو اس و الدو ائر معأ ونثمل: تحوير العرض و النهايات، ربط نهاية الى نهاية او نهاية الى حافة، تداخل، تعاثق، اختراق، تلاحم او نسيج، استمرارية و انغلاق (مخطط 4). 5. الزو ايا و القمم المدببة ونتثمل توظيف زو ايا مختلفة القياس (120, 90,60, 45, 30) وقد تكون حــادة او قائمسـة او

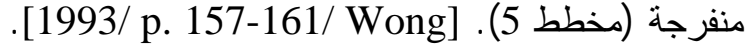

بينما عنصر المستوي الخاص بخلق او توليد الهيئات الهندسية فقد تمنل بتوظيف الاشكال الهندسية النقية كالمنتلـــ و المربع و الدائرة و السلسلة اللامتتاهية من المضلعات المشتقة منهما حيث "ان الاشكال المهدسية النقية كالمربع و الــدائرة

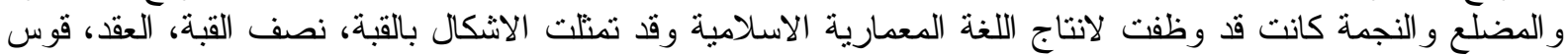

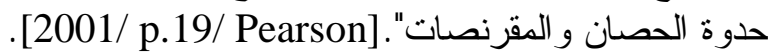
كما ان هذه الاثكال الهندسية تحكمها العلاقات و المباديء التالية:

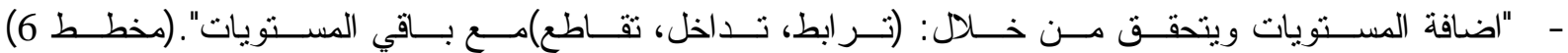
.[.]1993/ p.162/ Wong]

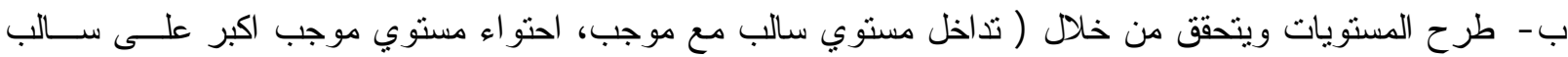

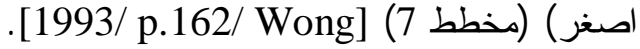

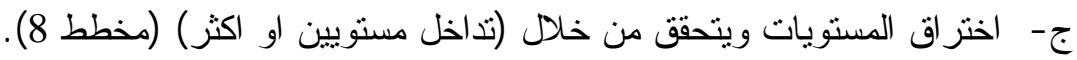

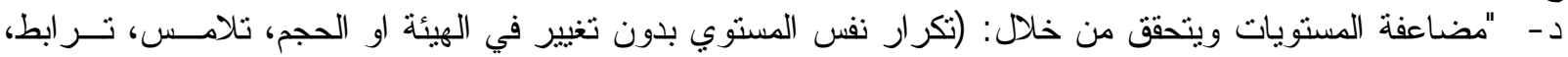

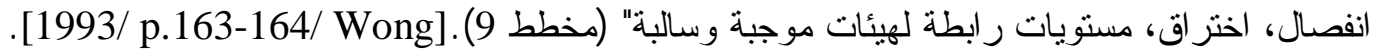

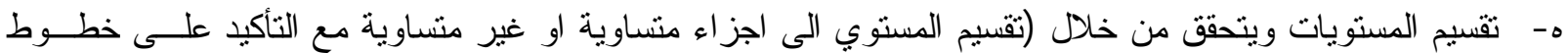
التقيم السالبة، الاز احات الخفيفة للهيئات المقسمة، الهيئات المنقسمة بامكانها التلامس و التز ابط، و التذاخل، و الاختــر اق)

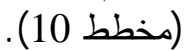

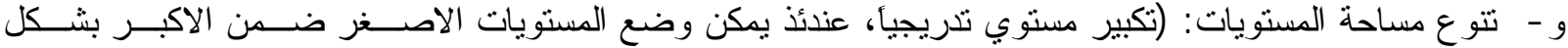

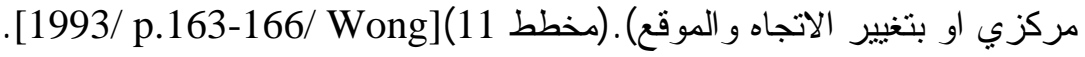

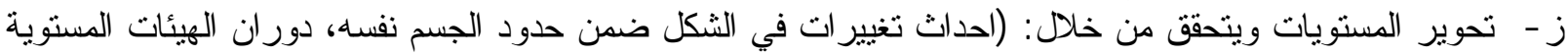
تدريجياً مما يؤدي الى تر اكبها مع تغيير في حجمها، تداخل الهيئات المحورة المتبادلة (مخطط 12) . ". /1993/p.167

. Wong]

ح - طي او ثني المستويات ويتحقق من خلال:(نشكيل زاوية مدببة أو مدورة عند طي مستوي، طي مدبب مــن خــلال

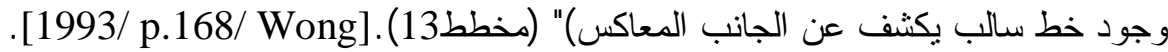

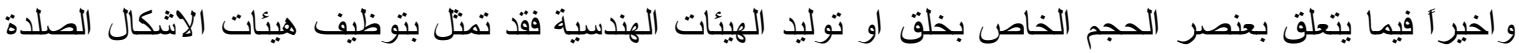
كالمكعب و الكرة و الهرم و المخروط و الاسطو الهُو انة و التي تحكمها العلاقات او المبادئ التالية:

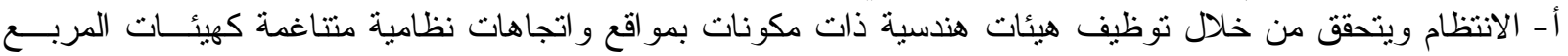

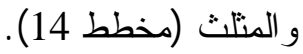

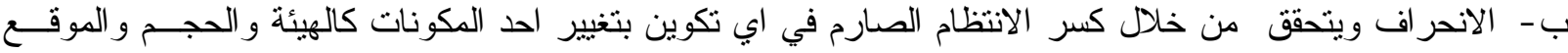
و الاتجاه بدون تغيير اساسي في التصميم(مخطط 15) . 1993/ p.169-170/Wong].

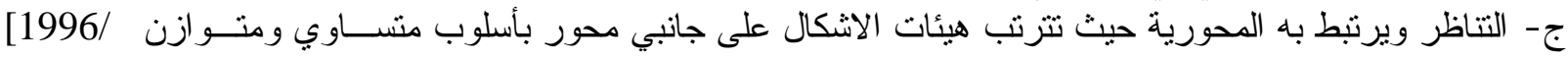

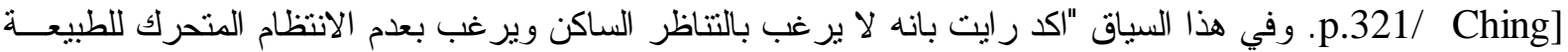
في هيئات مبانيه" (مخطط 16).

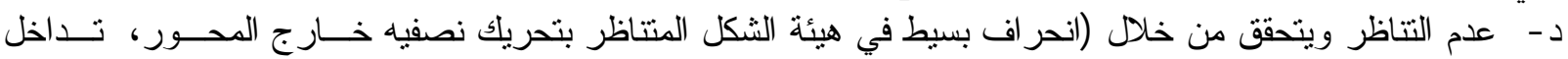
نصفيه، اضافة بعض التغيير لاحد النصفيين) (مخطط 17). 11993/p.171/Wong].

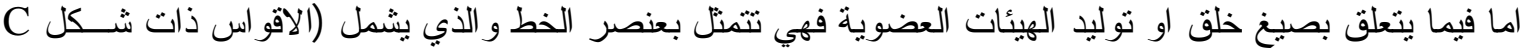

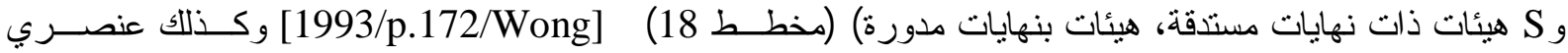




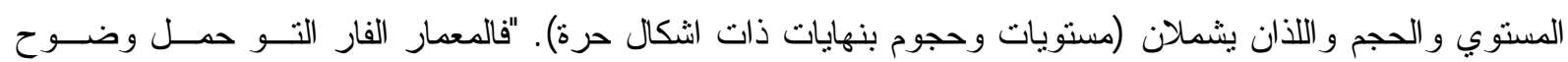

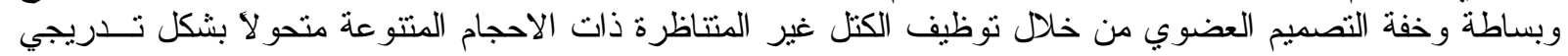

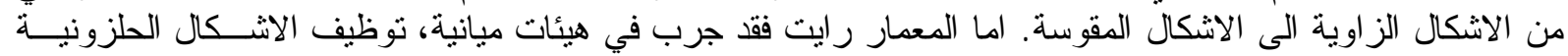

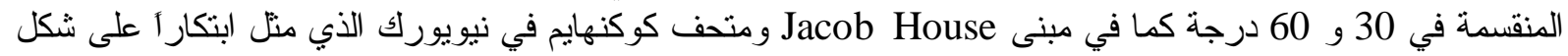

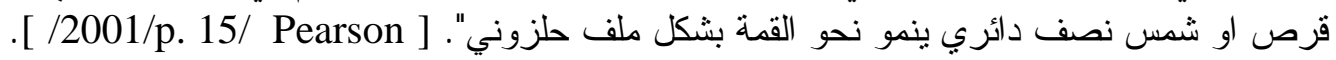

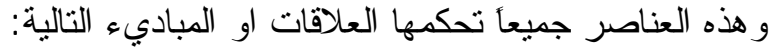

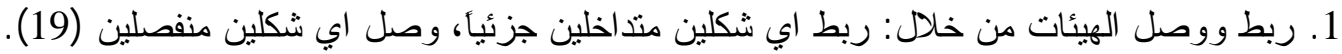

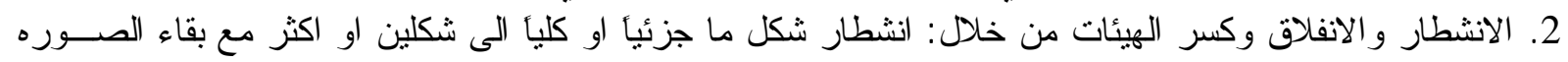

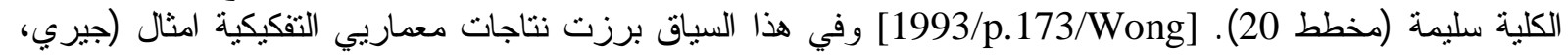

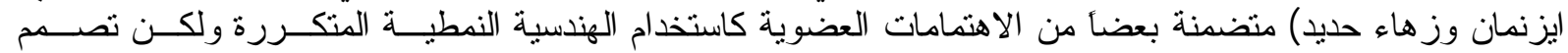

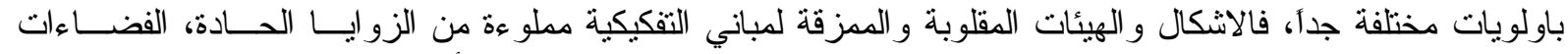

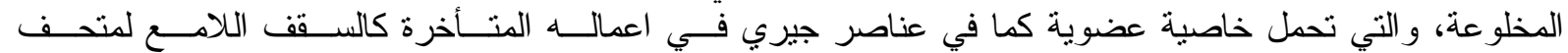

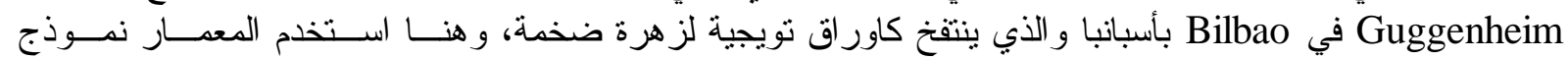

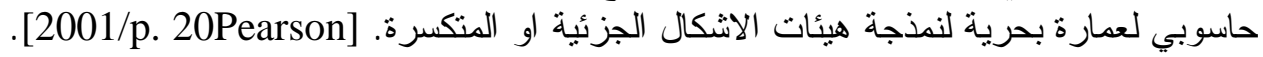

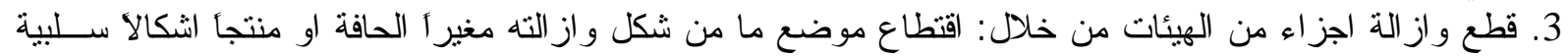
مع نرك الحافات لتجسيد كسر اجباري" (مخطط 21).

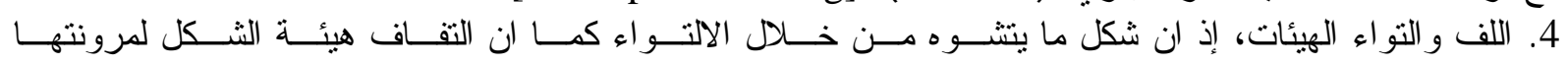

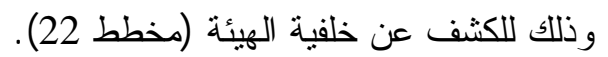

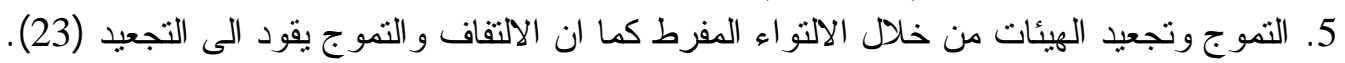

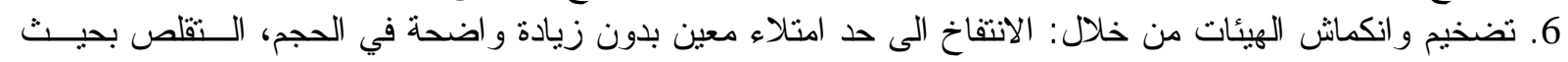

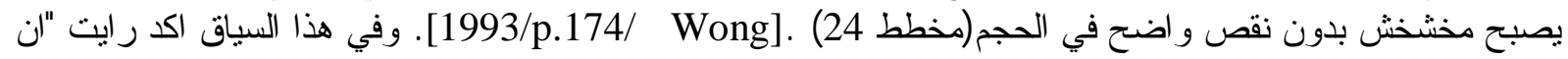

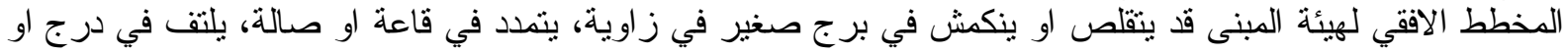

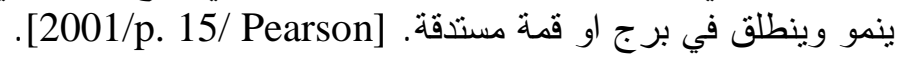

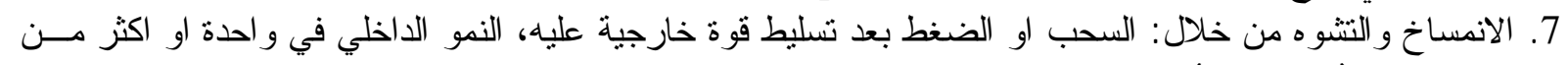
مساحات الثكل (مخطط 25). 8. التكاثر او التو الد من خلال: الاستخدام المضاعف لهيئة ما مع اختلاف شكل وحجم العناصــر المتداخلـــة المتكـــثرة (مخطط 26) (ل)

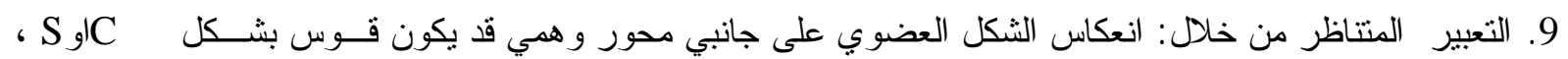
تحوير مكونات هيئة الشكل قليلا دون تدمير تتاظر الهيكل(مخطط 27) .

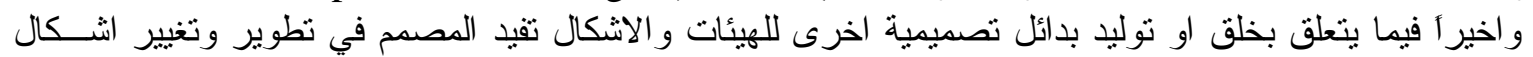

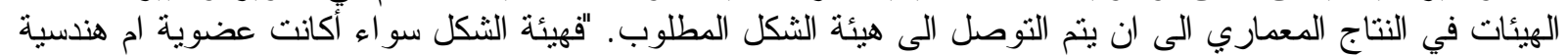

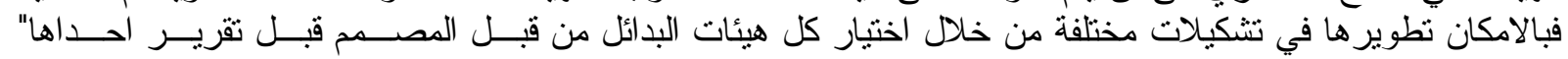
[1993/p.180/Wong]

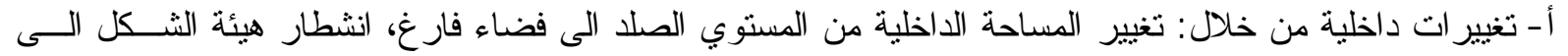

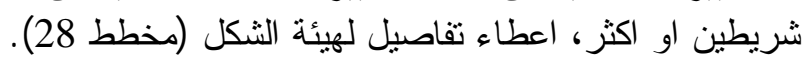

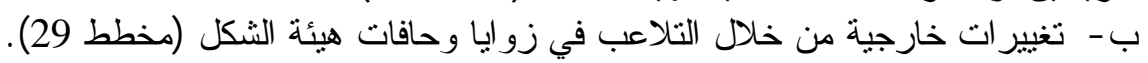

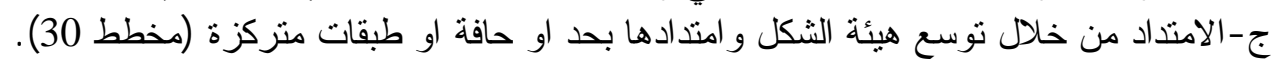

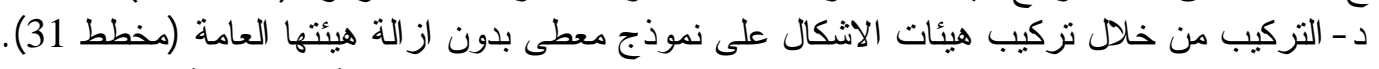

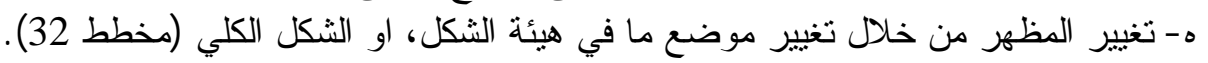

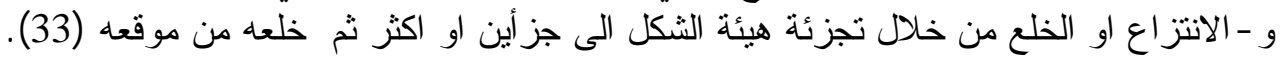

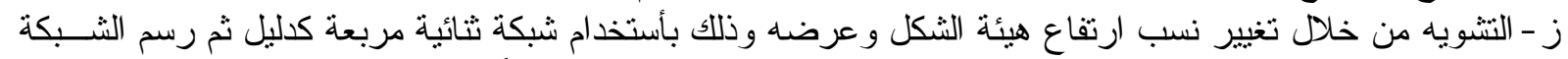

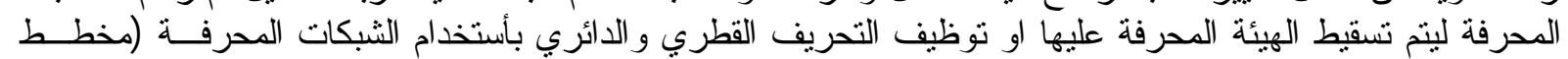

.[1993/p.179-183/Wong] . 34

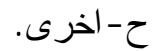

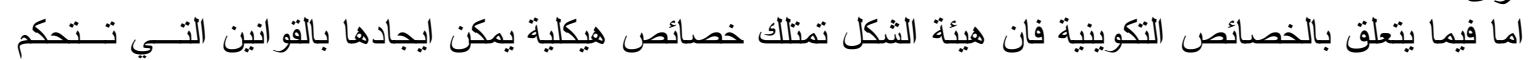

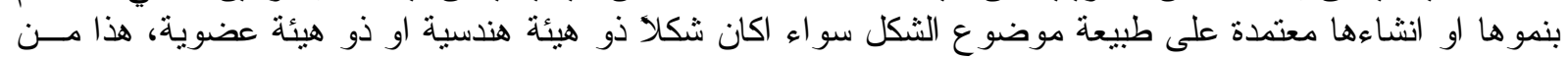




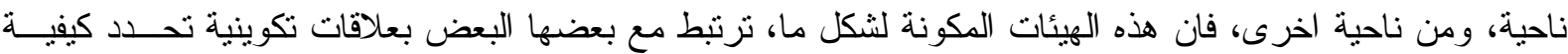

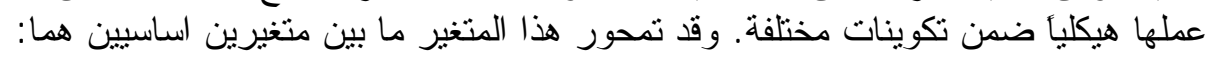

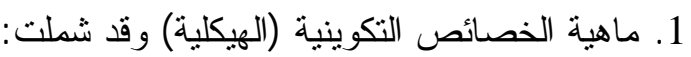

$$
\text { أ - خصائص طبيعية. }
$$

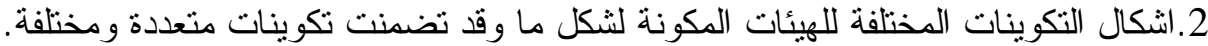

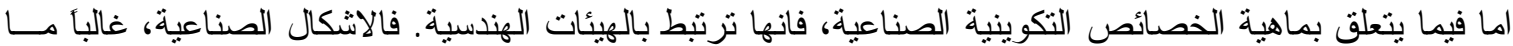

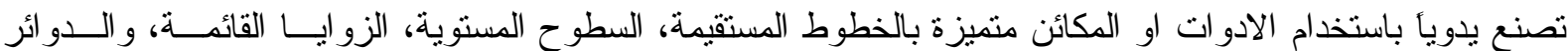

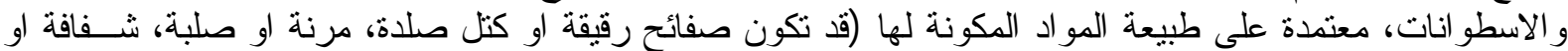

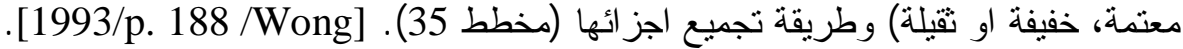

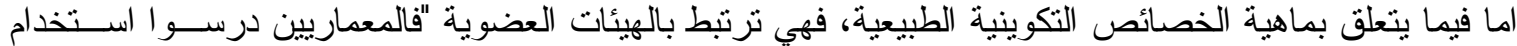

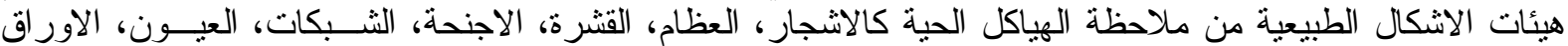

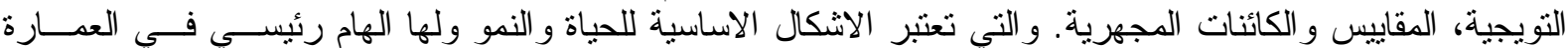

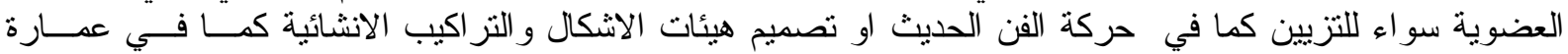

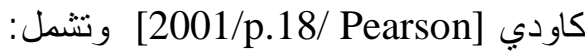

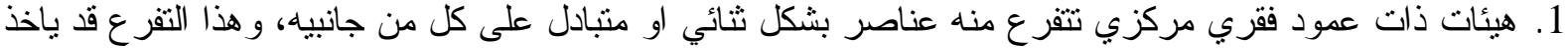

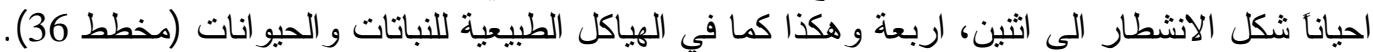
2. هيئات تتفرع على شكل مروحة وتمند بز اوية 360 بعناصر دوارة الفئ مركزية او محيطية بمركز كبير مفتوح (مخطط

3. هيئات خطية ملتفة باتجاه واحد او اكثر متخذة هيئات حلزونية او مخروطية او اسطو انية او منموجة (مخطط 38). د1993/p. 188 /Wong]

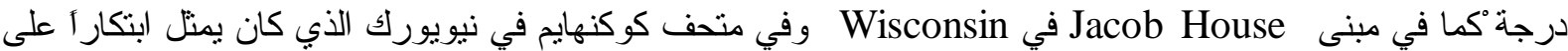
شكل قرص او شمس دائرية تنمو نمو القمة بشكل ملف حلزوني[2001/p. 18/ Pearson].

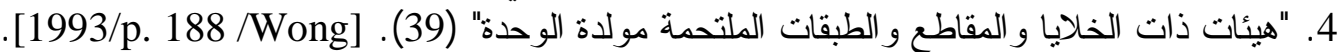

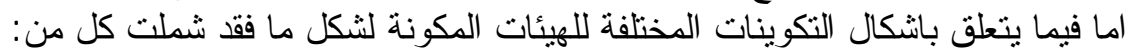

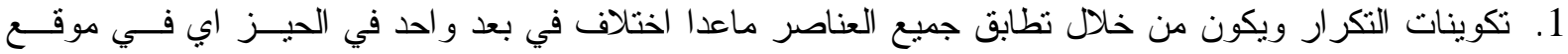

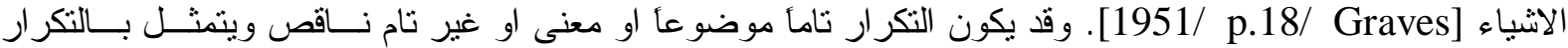

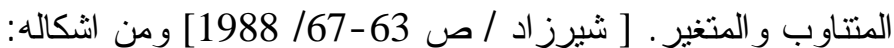

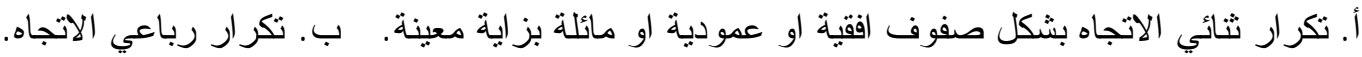

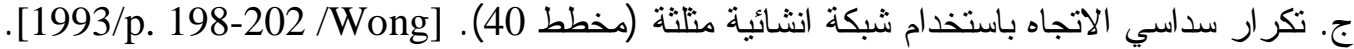

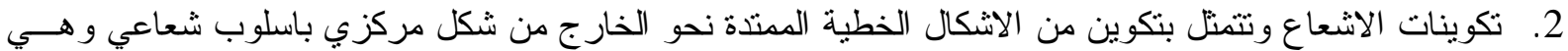

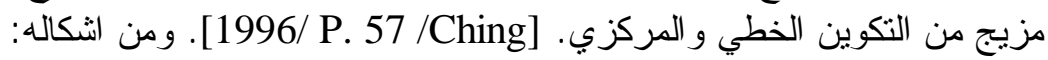

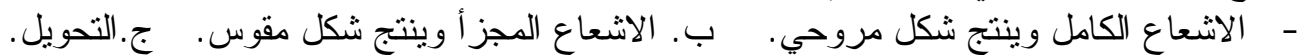

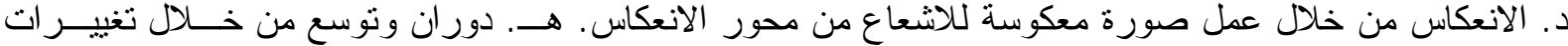

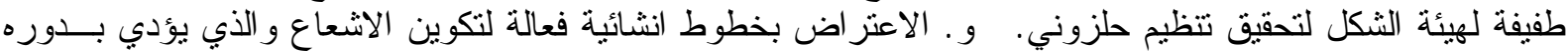

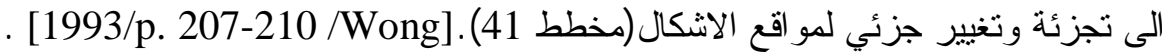

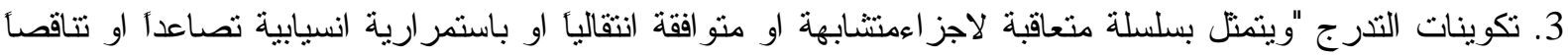
لمختلف العناصر". [ تثيرز اد/ ص 142/ 1988] ومن اشكاله:

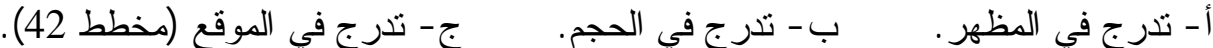

$$
\begin{aligned}
& \text { د - ندرج الاتجاه }
\end{aligned}
$$

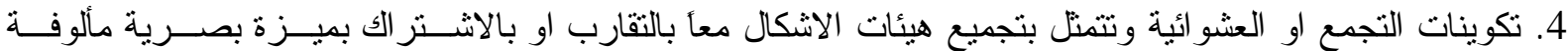

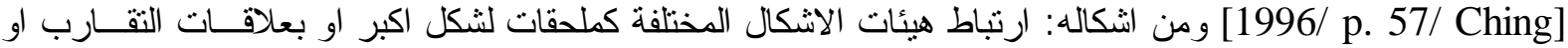

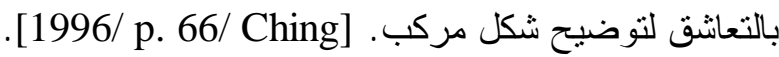

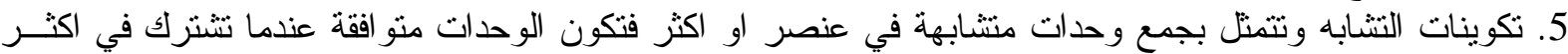

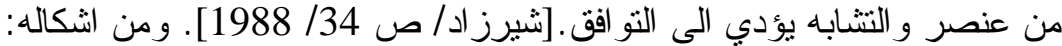

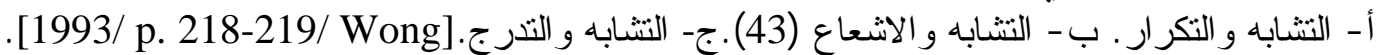




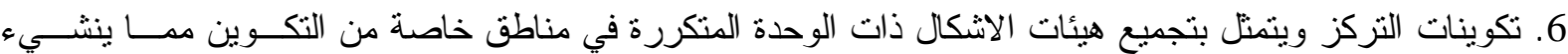

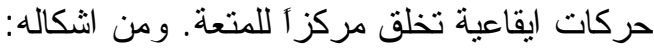

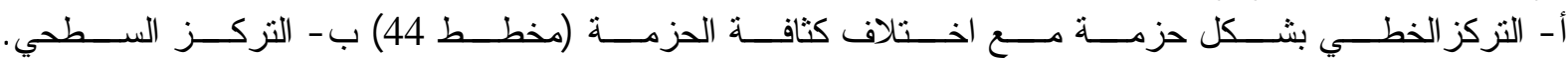
.[1993/ p. 219-222/ Wong]

7. تكوينات التضاد ومن اشكاله:

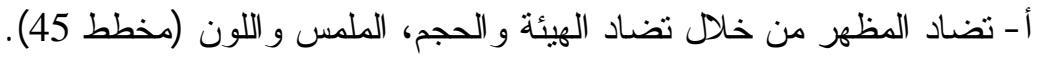

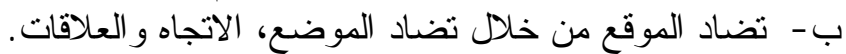

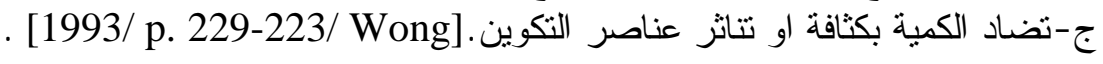

8. التكوينات الثبكية فالثبكات تتنج من تكر ار الاشكال الهندسية الاساسية من خلال عمليـات المضـــاعفة، الارتبــاط، التقسيم و التحوير ومن الثكاله:

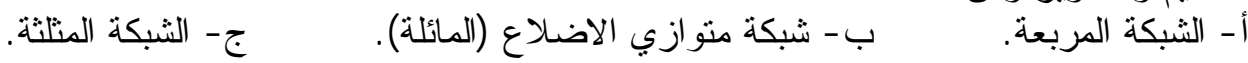

9. تكوينات الثذوذ وتتمنل بجمع عناصر نظامية ولا نظامية في تصميم ما، عندما تكون العناصر النظامية اكثر عـدداً

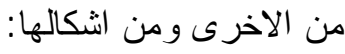

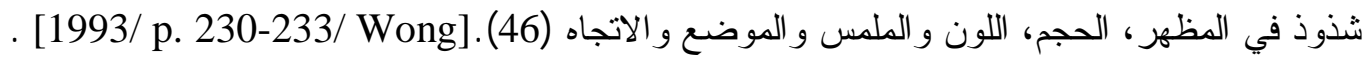

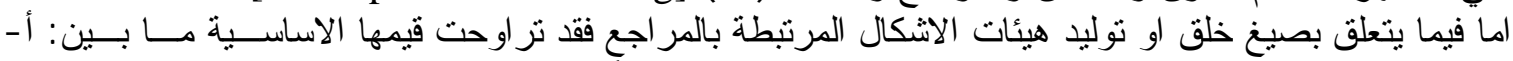

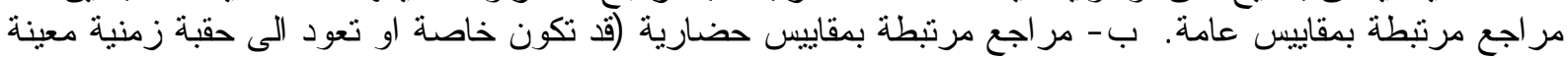

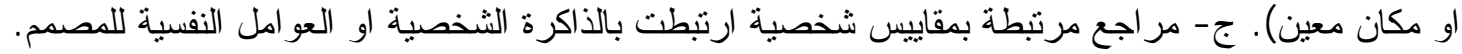

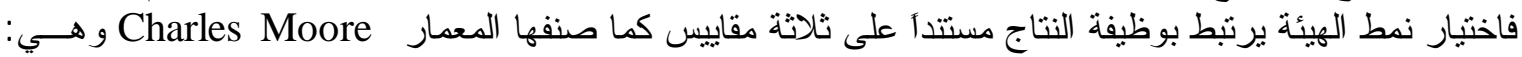
العامة و الثقافية و الثخصية.

امسا المقاييس العامة فيقصد بها"تلك المشتركة على نحو عام (Commonly shared)و المتمنلـــة بــالطرز البدئيـــة

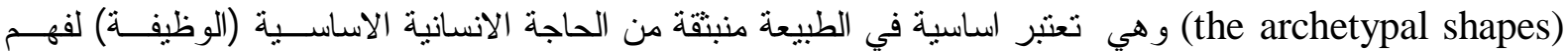

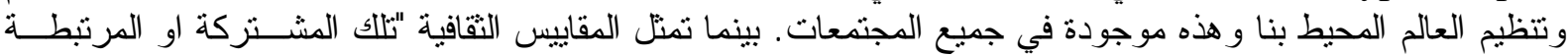

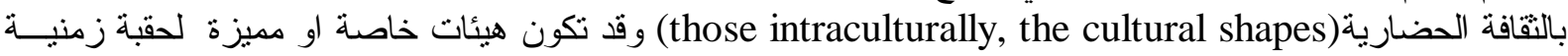
معينة او لككان او اقليم معين كما في تصاميم حقبة القرن 19 المثيرة لذكريات الحقبة الغوطية وكذلك التصاميم الحاليـة التهة لما بعد الحداثة المرتبطة بالحقبة الكلاسيكية" [1992/ p. 50/ Malnar, Vodvarka.

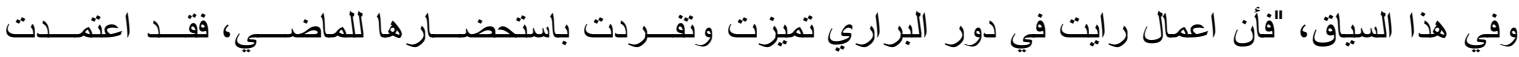

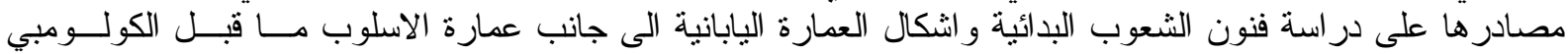

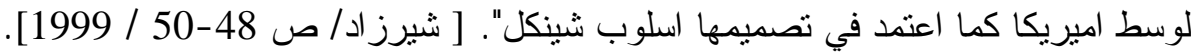

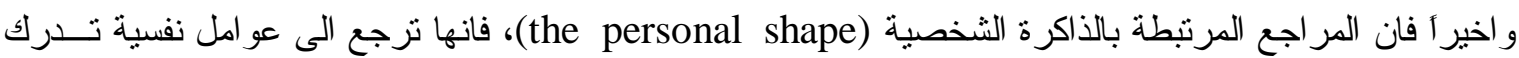

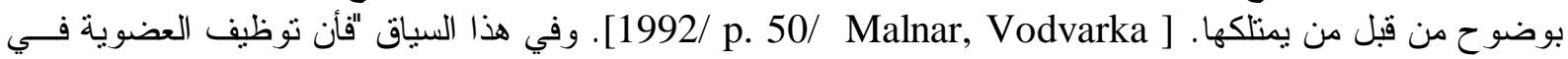

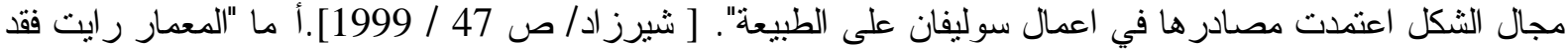

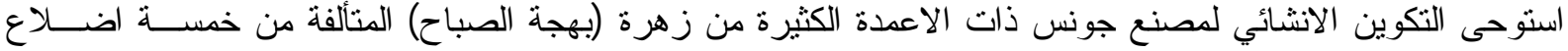

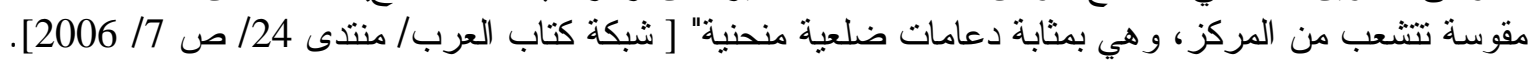
يوضح جدول [4 -2] المفردة الثانية. 

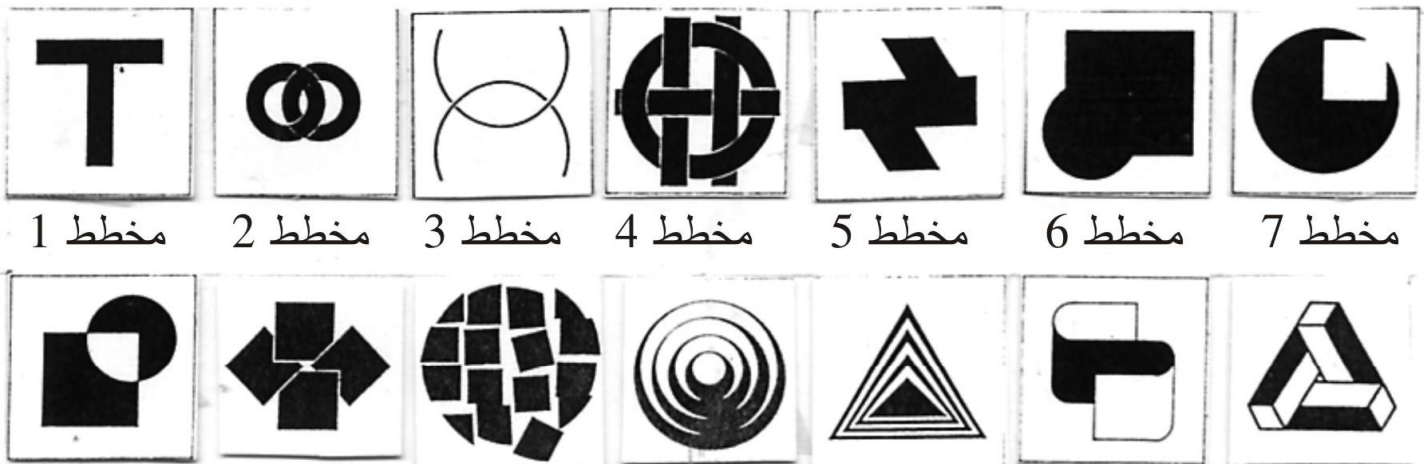

8 مخطط 8
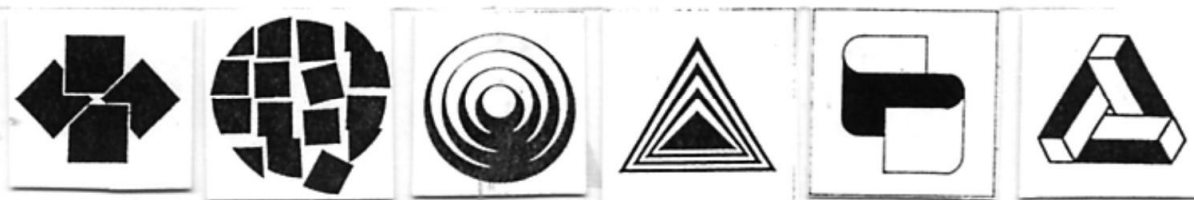

9 مخطط

10 مخطط
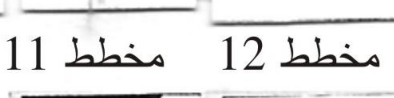

مخطط 13

مخطط 14
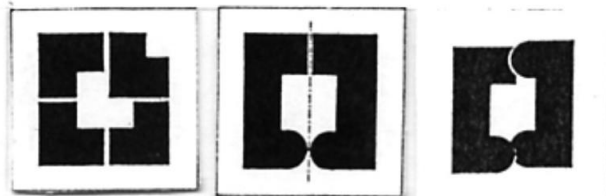

مخطط 15

مخطb 16

مخطط
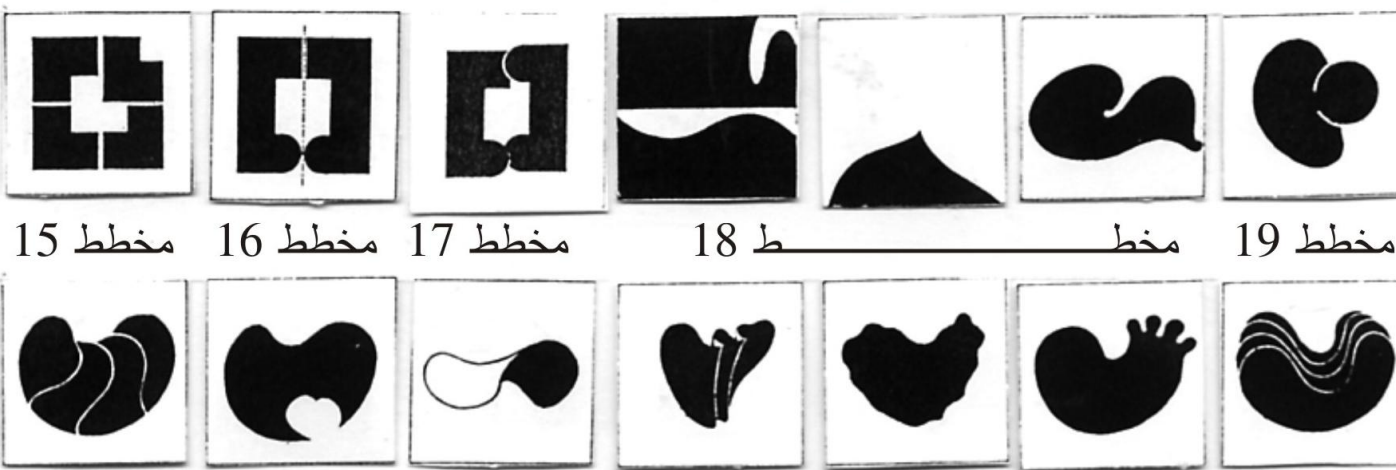

18 b

مخط

مخطط 19

مخطط 20

مخطط 21

مخطb 23
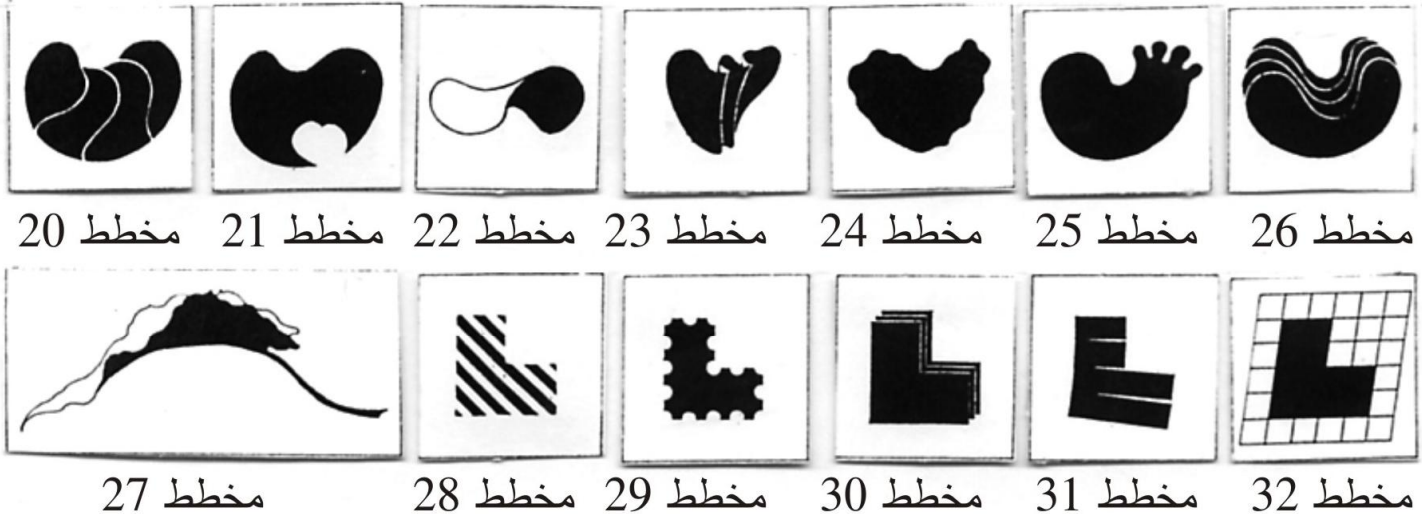

مخطط 23

مخطط

مخطط

مخطط 26

\section{مخطط 27}
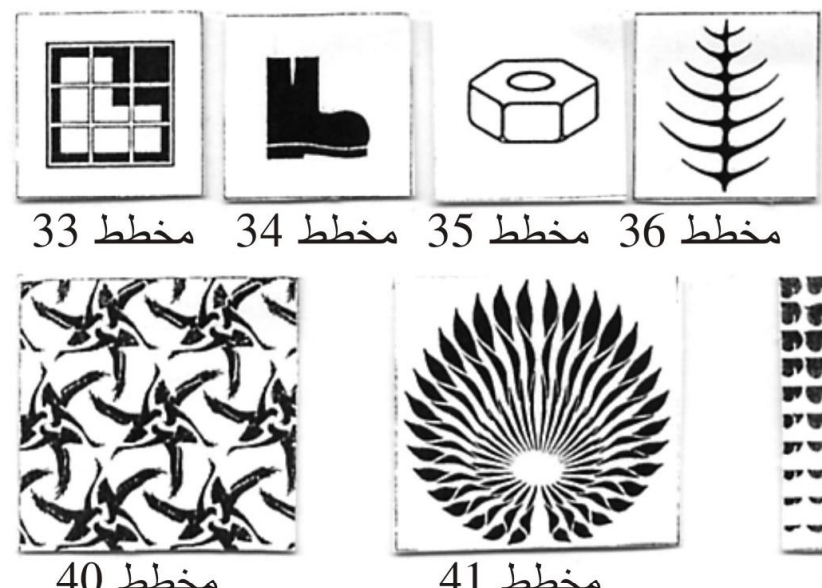

مخطط 40
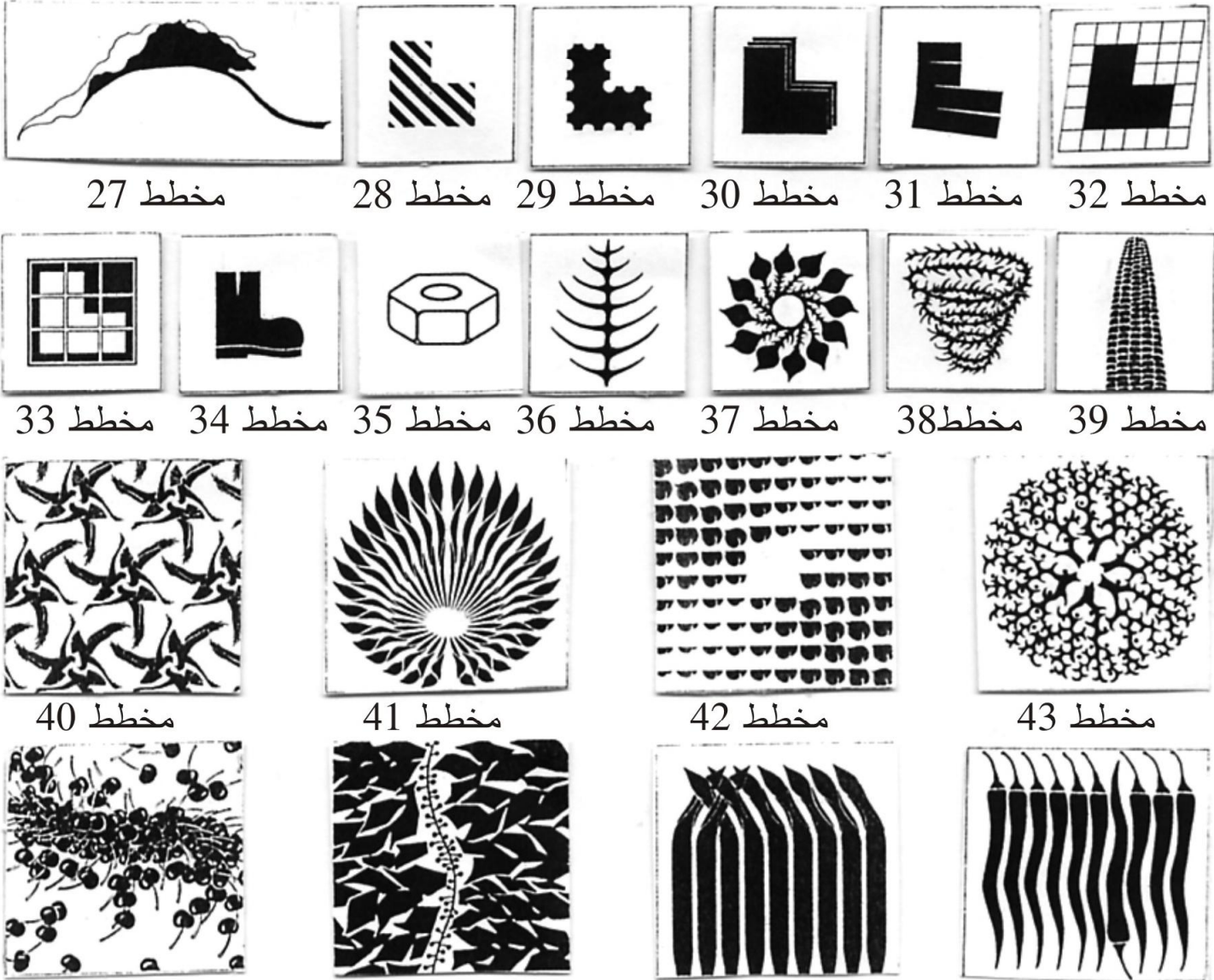

مخطط 30

مخطط 32 مخطط

مخطط 44

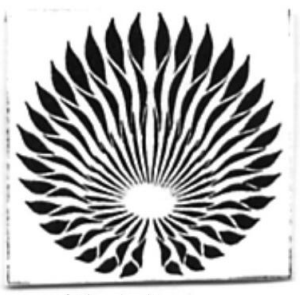

مخطط 41

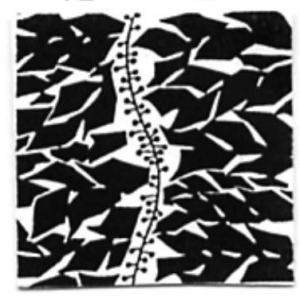

مخطط 45

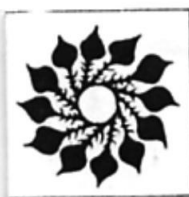

مخطط

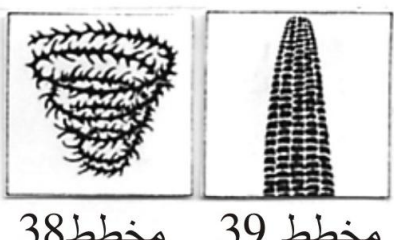

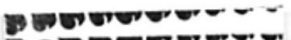

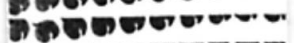

(P)

Cด

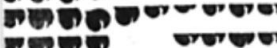

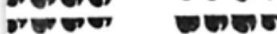

mereverpin

m-r-arguar

- - - verever.

42 bis.
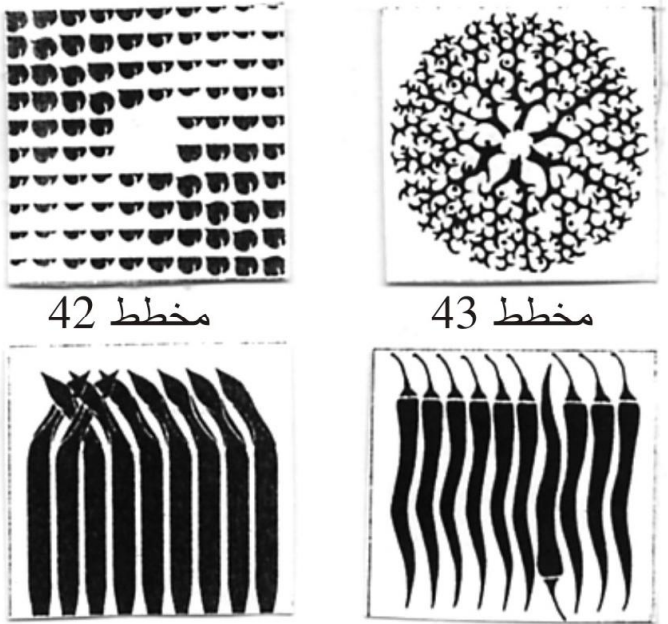

46

مخط 
الثيخ : وصف عنصر الهيئة في التكوين المعماري وصيغ توليد انماطه في نتاجات المعمار رايت

جدول [4-2]: القيم المكنة للمفردة الثانية: صيغ توليل (تحقق) الهيئة:

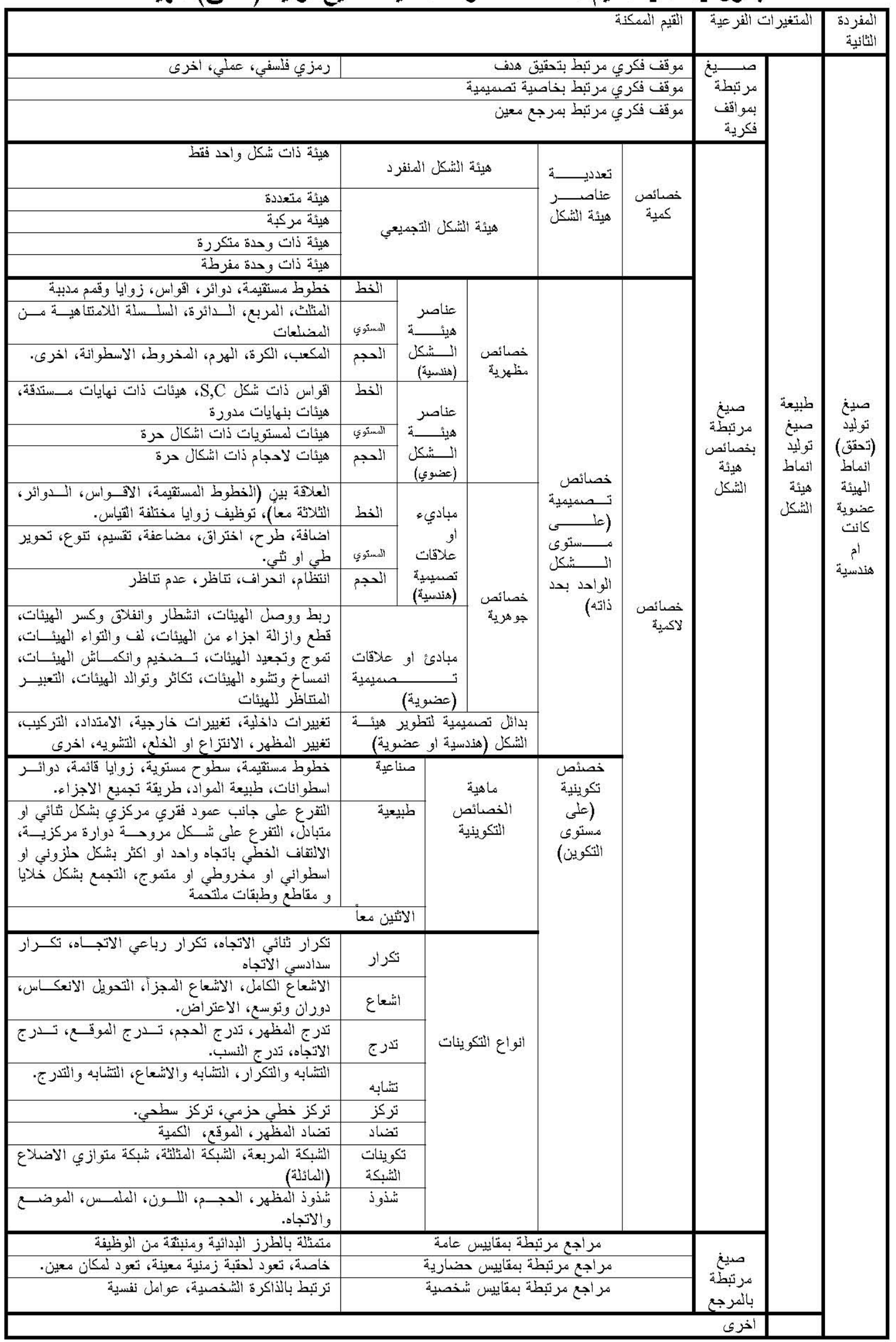




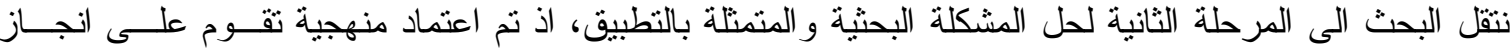

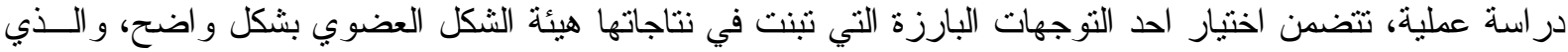

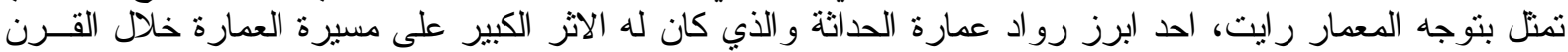

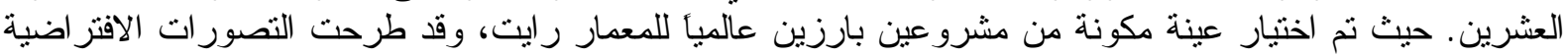

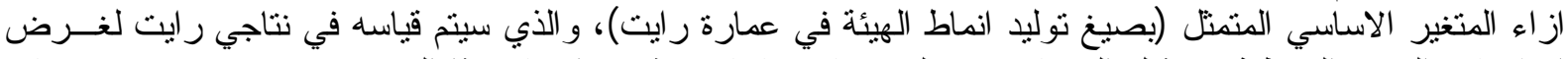

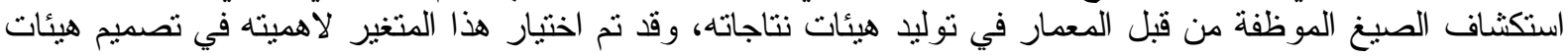

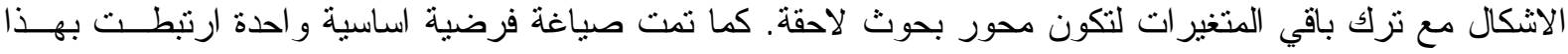

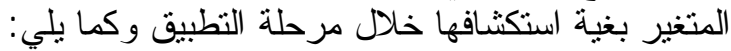

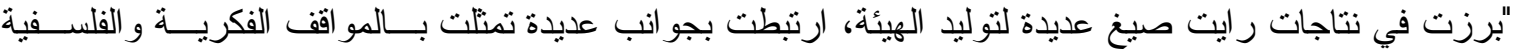

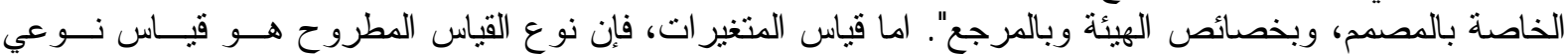

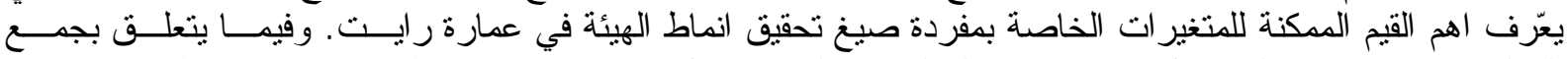

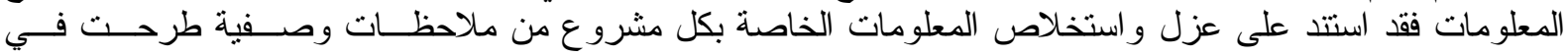
الدر اسات المعمارية.

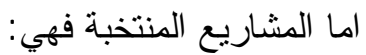

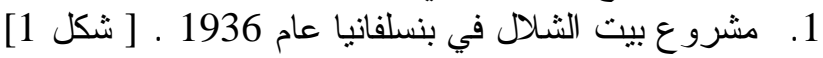

2. مشروع متحف كوكنهايم في نيويورك فئن عام 1943 - 1959.

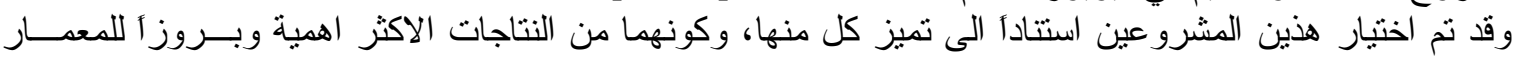

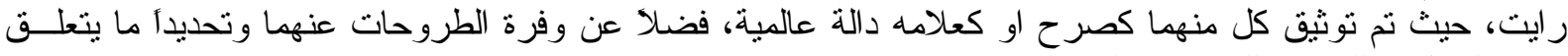

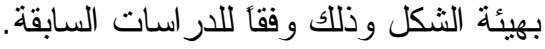

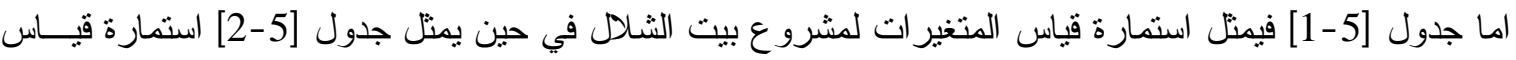

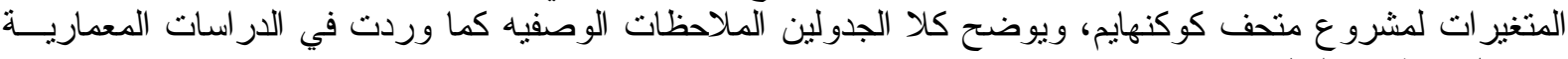

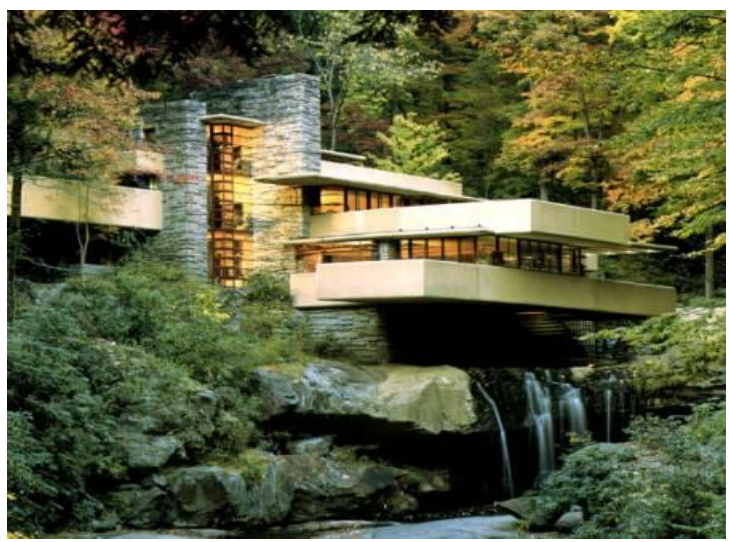
از اء كل قيمة قيد التطبيق.
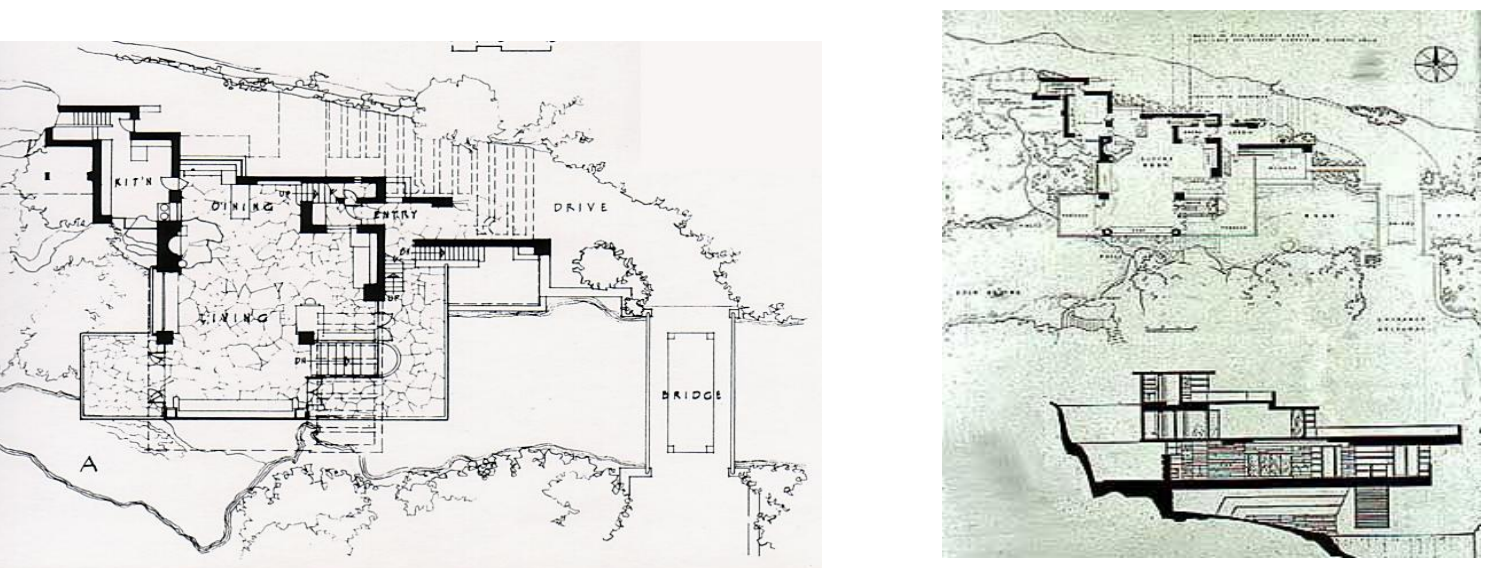

[ثكل1] بيت الشالل في بنسلفانيا للمعمار رايت، 1936 
الثيخ : وصف عنصر الهيئة في التكوين المعماري وصيغ توليد انماطه في نتاجات المعمار رايت
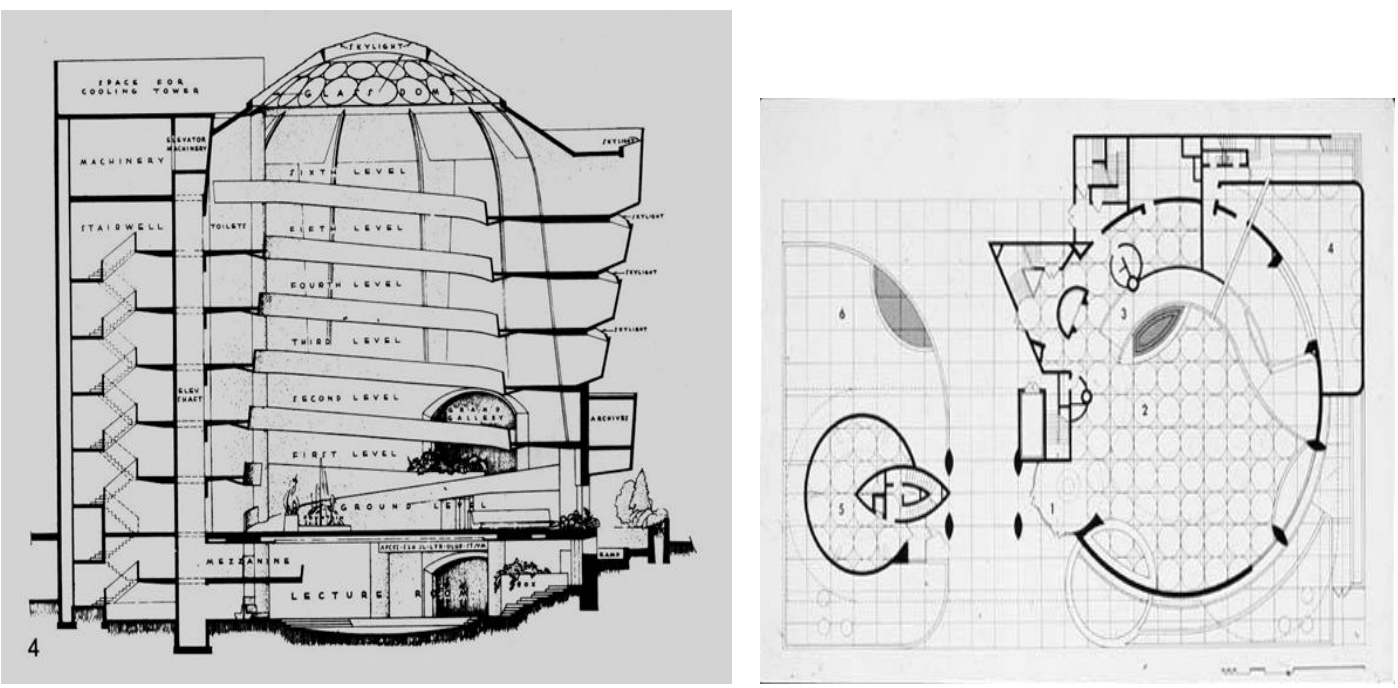

setion,

plan متحف كوكنهايم
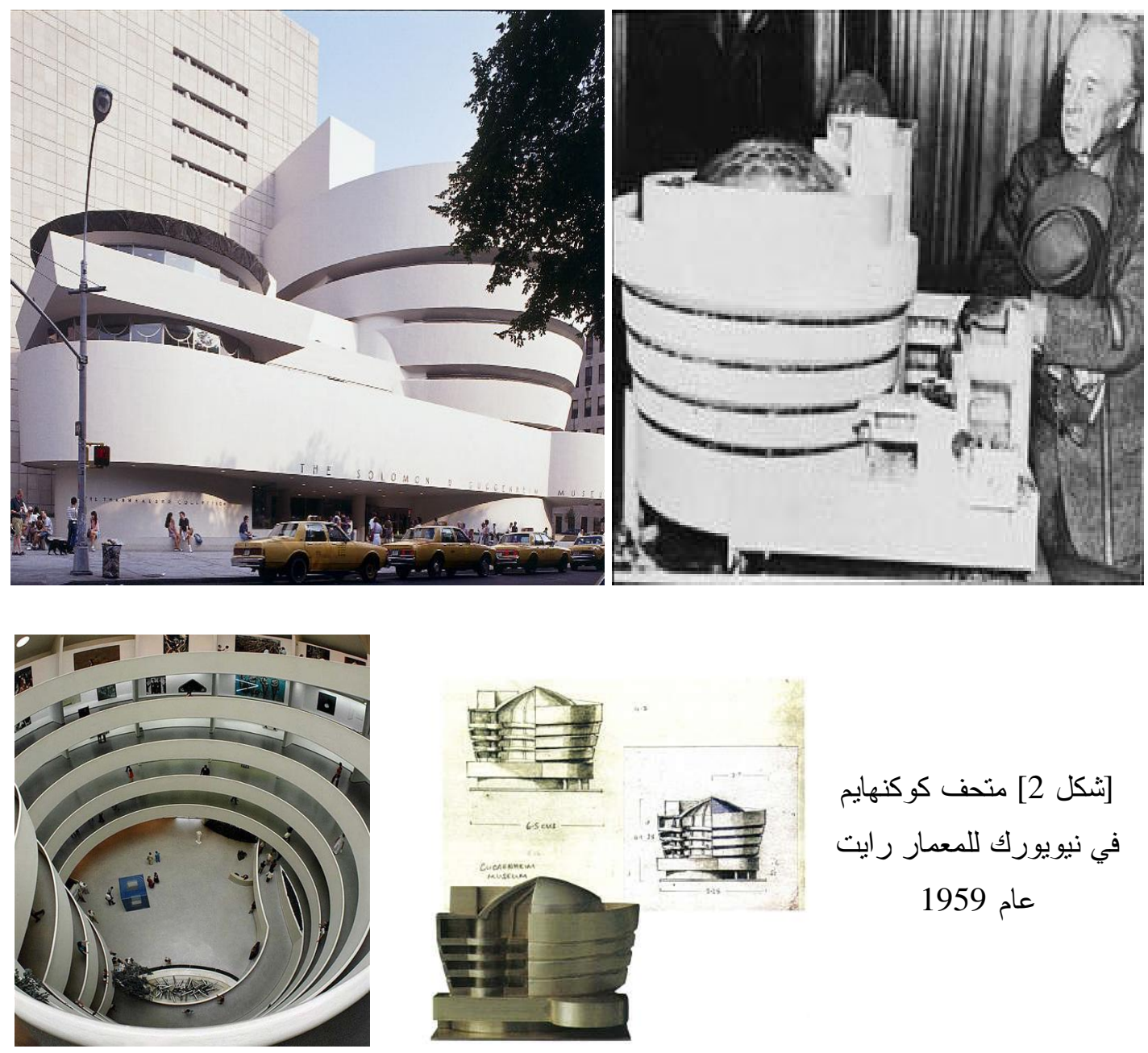

[شكل 2] متحف كوكنهايم

في نيو يورك للمعمار رايت عام 1959 
جدول [5 -1] : استمارة قياس المتغير ات لمشروع بيث الشلال في بنسلفانيا عام 1936:

\begin{tabular}{|c|c|c|c|c|}
\hline الوصفات الممكنة & \multicolumn{2}{|c|}{ القيم الممكنة } & المتغير ات & الثفردة المفية \\
\hline 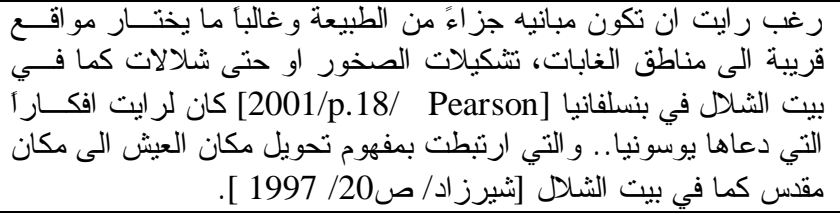 & \multicolumn{2}{|c|}{ موقف فكري مرتبط بتحقيق هدف } & \multirow{3}{*}{ 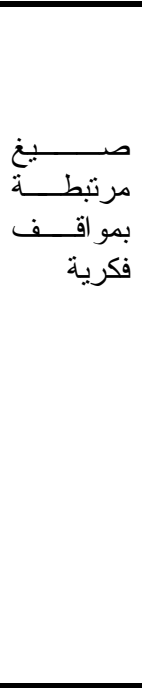 } & \\
\hline 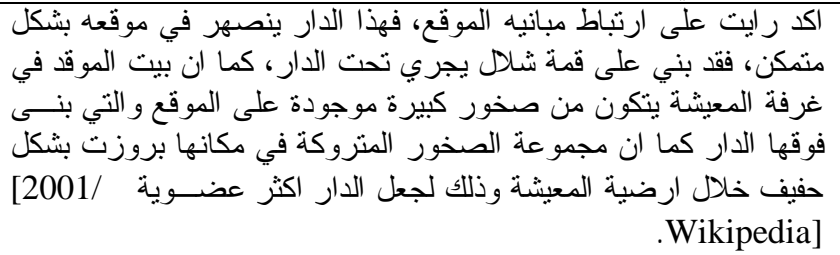 & رنبط بتحقيق خاصية & موقف فكري م & & \\
\hline 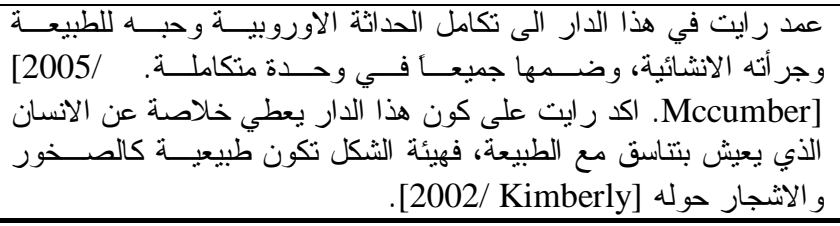 & رتبط بالمرجع & موقف فكري م & & \\
\hline & هيئة منفردة & \multirow{5}{*}{ كمية لــــائص } & & \\
\hline 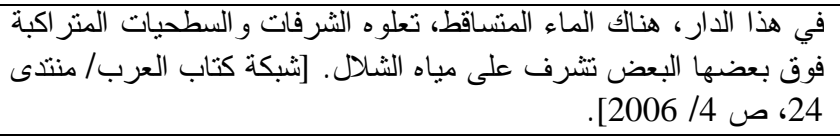 & هيئة متعددة & & & \\
\hline & هيئة مركبة & & & \\
\hline & هنكررة هينـة ذات وحــــة & & & \\
\hline & هفرطة هئـة ذات وحــــة & & & \\
\hline \multirow{2}{*}{ 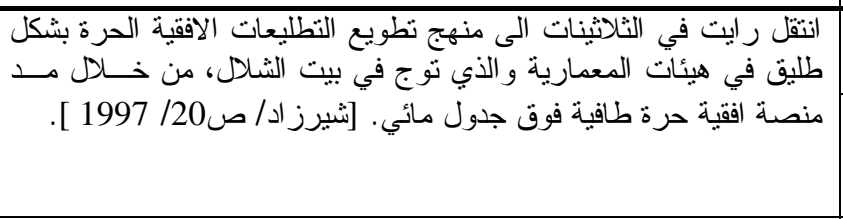 } & |هندسر الخط/| & & & \\
\hline & خطوط مستقيمة & & & \\
\hline \multirow{2}{*}{ 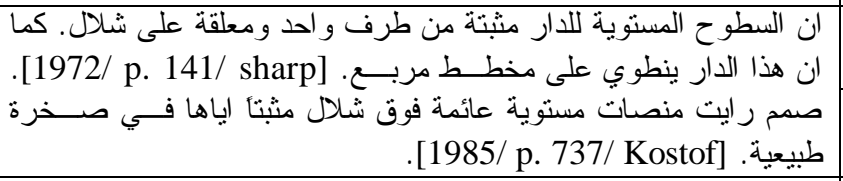 } & هندسري المسـتوي/ & & & \\
\hline & 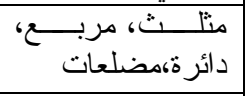 & & & \\
\hline \multirow[t]{5}{*}{ 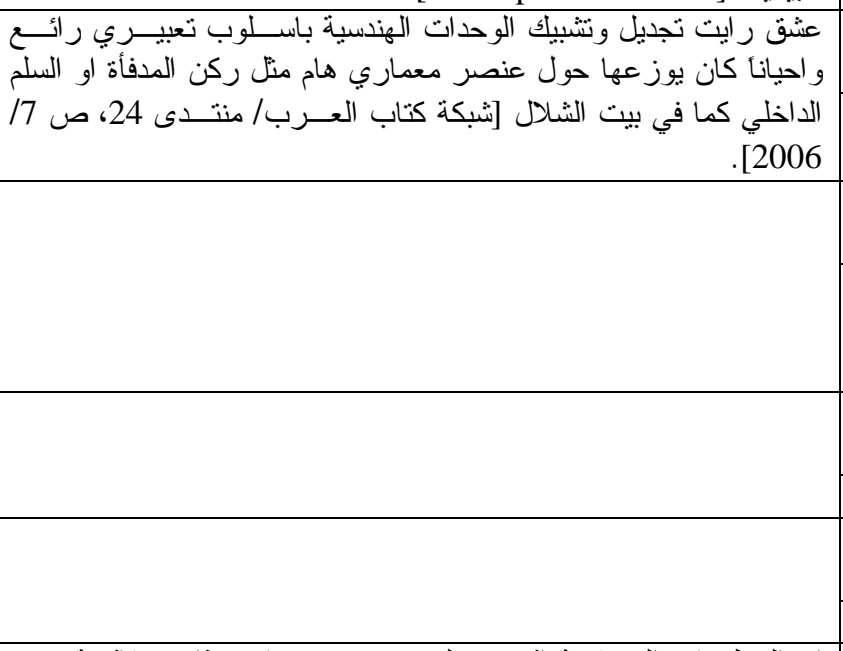 } & 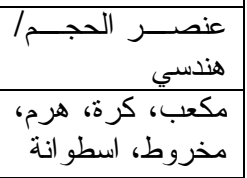 & & & \\
\hline & 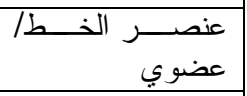 & & & \\
\hline & 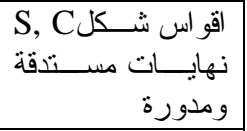 & & & \\
\hline & 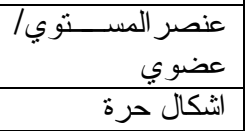 & & & \\
\hline & 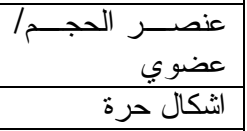 & & & \\
\hline 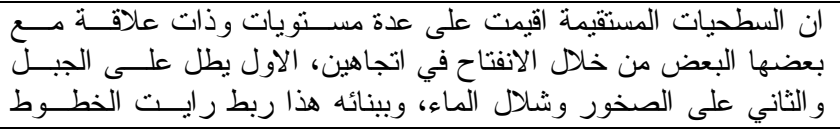 & 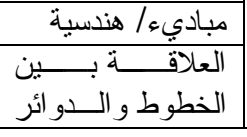 & & & \\
\hline
\end{tabular}


الثيخ : وصف عنصر الهيئة في التكوين المعماري وصيغ توليد انماطه في نتاجات المعمار رايت

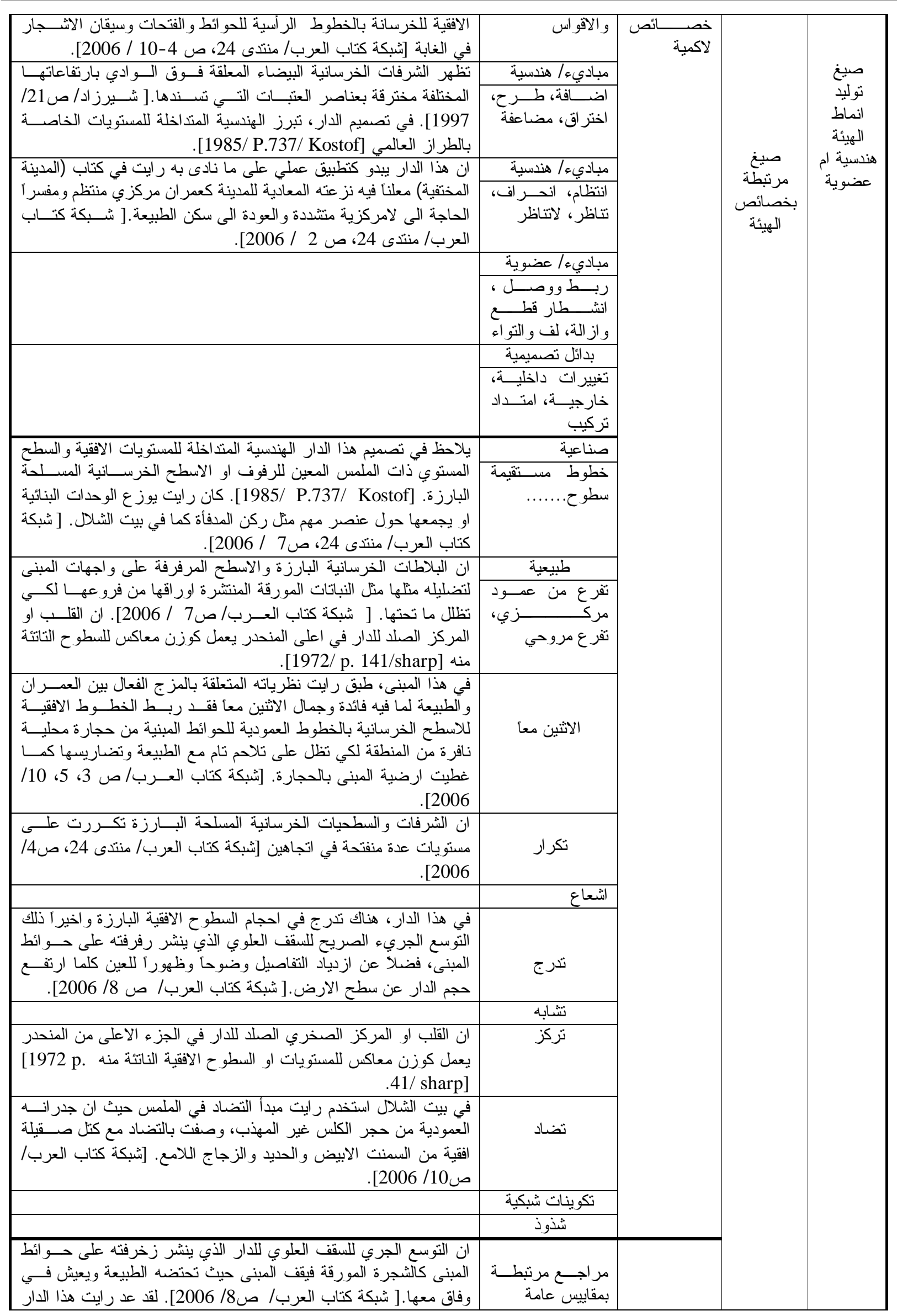




\begin{tabular}{|c|c|c|}
\hline 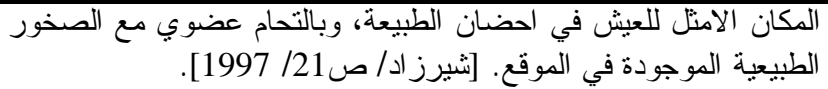 & & صيغ مرتبطة \\
\hline 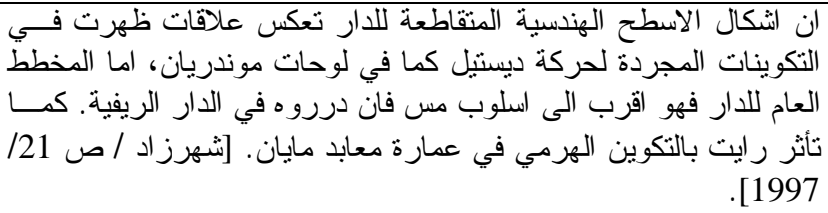 & بمقاييس حضع مرتبطــــة & \\
\hline 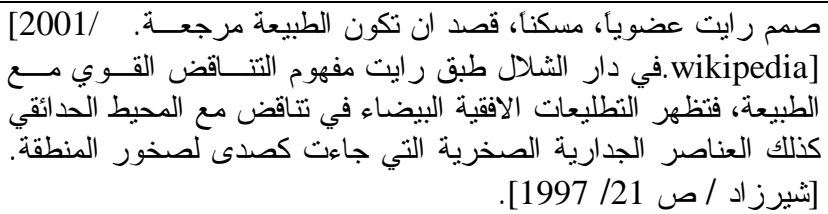 & بمقاييس شخع مرتبطة & \\
\hline
\end{tabular}

جدول [5 -2]: استمارة قياس المتغيرات لمشروع متحف كوكنهايم في نيويورك عام 1959

\begin{tabular}{|c|c|c|c|c|}
\hline الوصفات الممكنة & \multicolumn{2}{|r|}{ 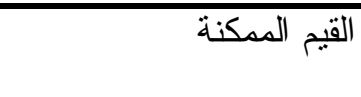 } & الفرعية المتغير & الثانية لــردة \\
\hline 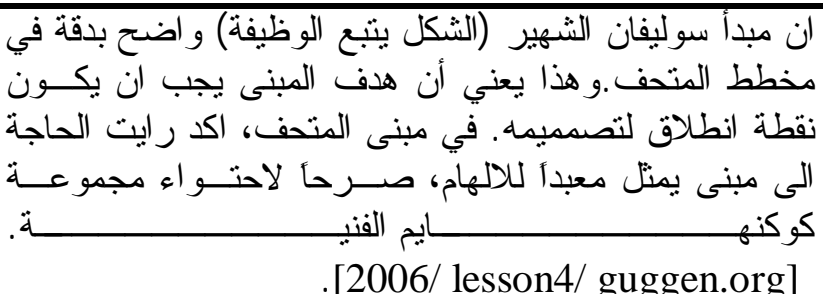 & \multicolumn{2}{|c|}{ موقتق فدفــري مسـرتبط } & \multirow{3}{*}{ 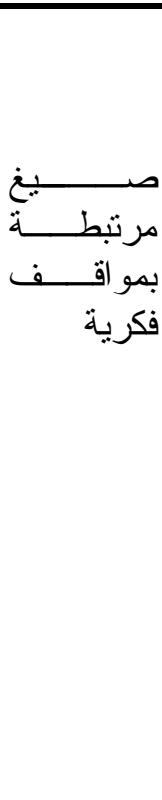 } & \multirow{8}{*}{ 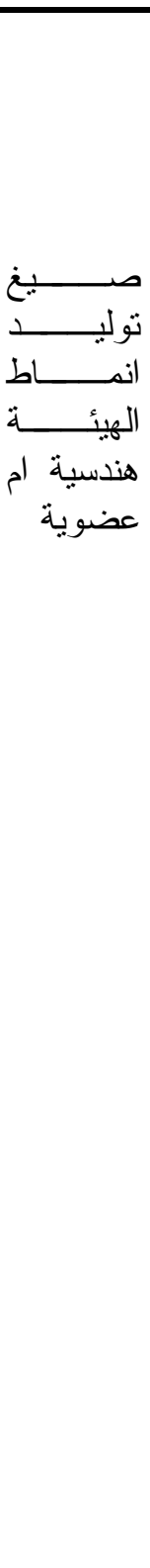 } \\
\hline 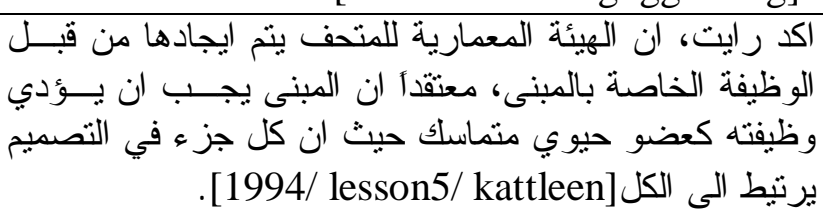 & ي مسرتبط & 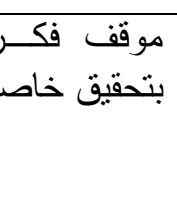 & & \\
\hline 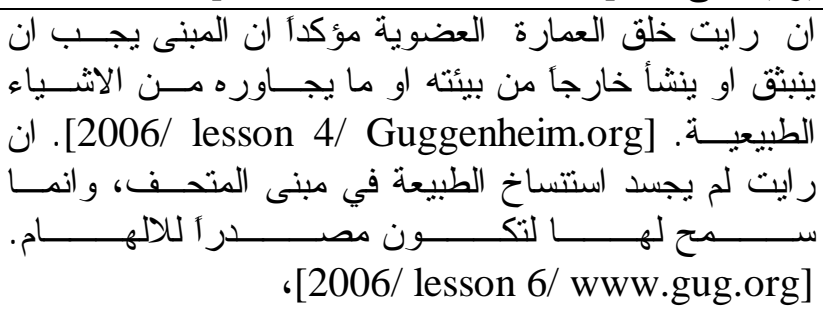 & ي مسرتبط & 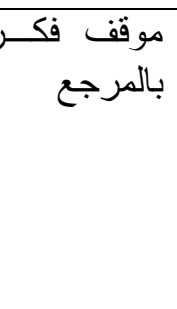 & & \\
\hline & هنفردة هيأيـــــة & \multirow{6}{*}{ كمية } & \multirow{6}{*}{ مرنبط لخـنة } & \\
\hline 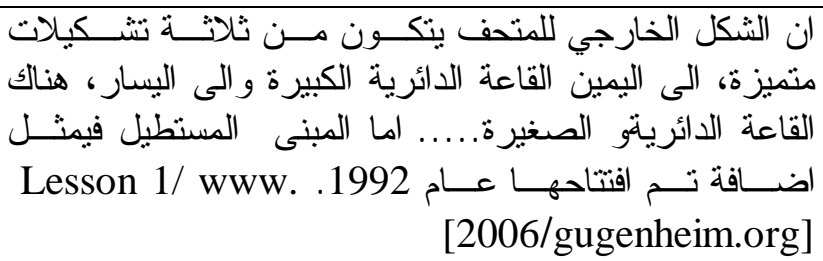 & هيبئـــــــة & & & \\
\hline & هركبية & & & \\
\hline & هئــــة ذات & & & \\
\hline & هفئُسة ذات & & & \\
\hline 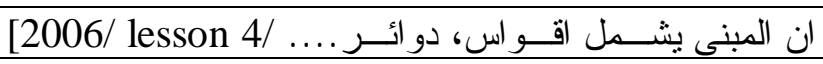 & عنصــــــــــ & & & \\
\hline
\end{tabular}




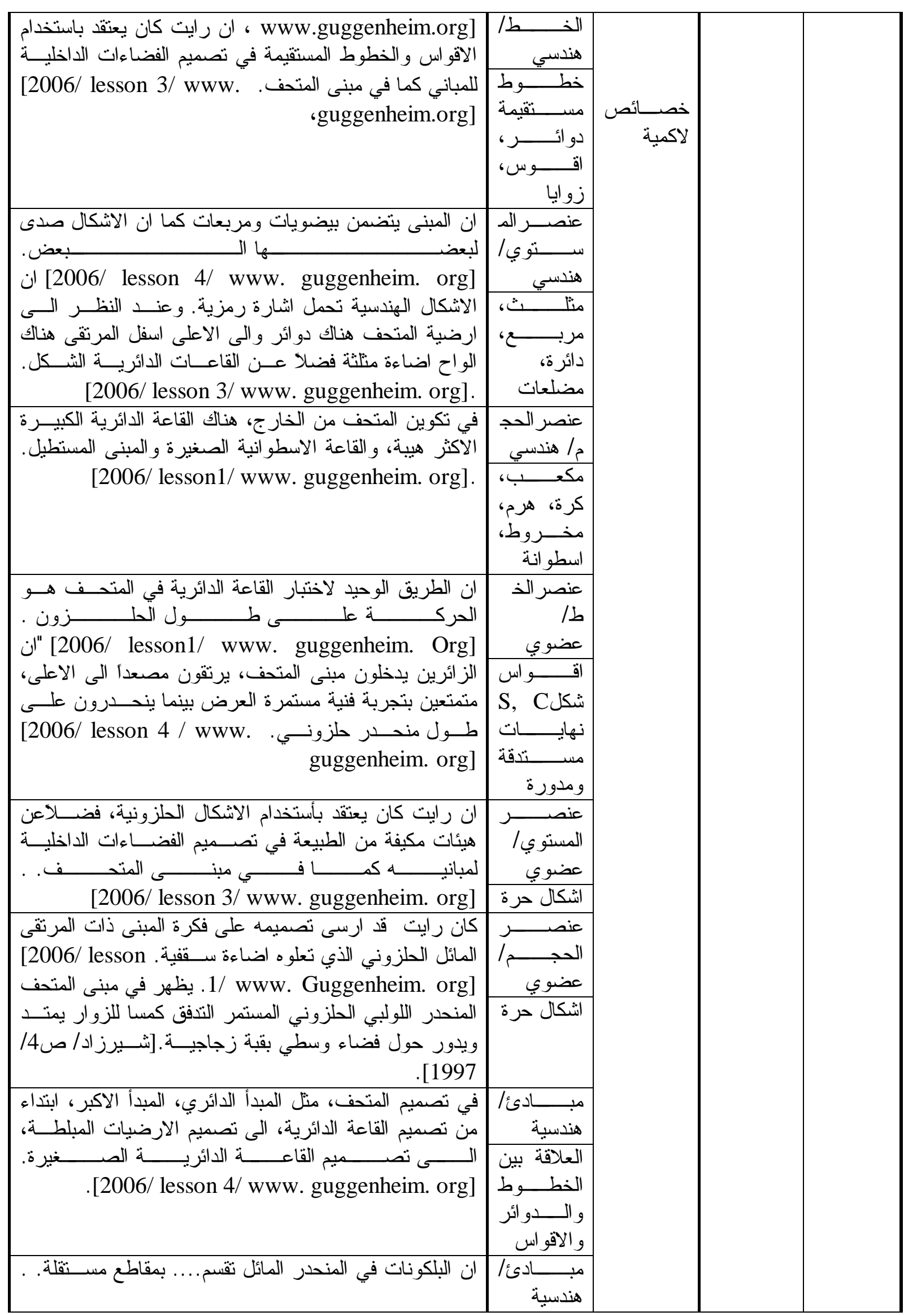




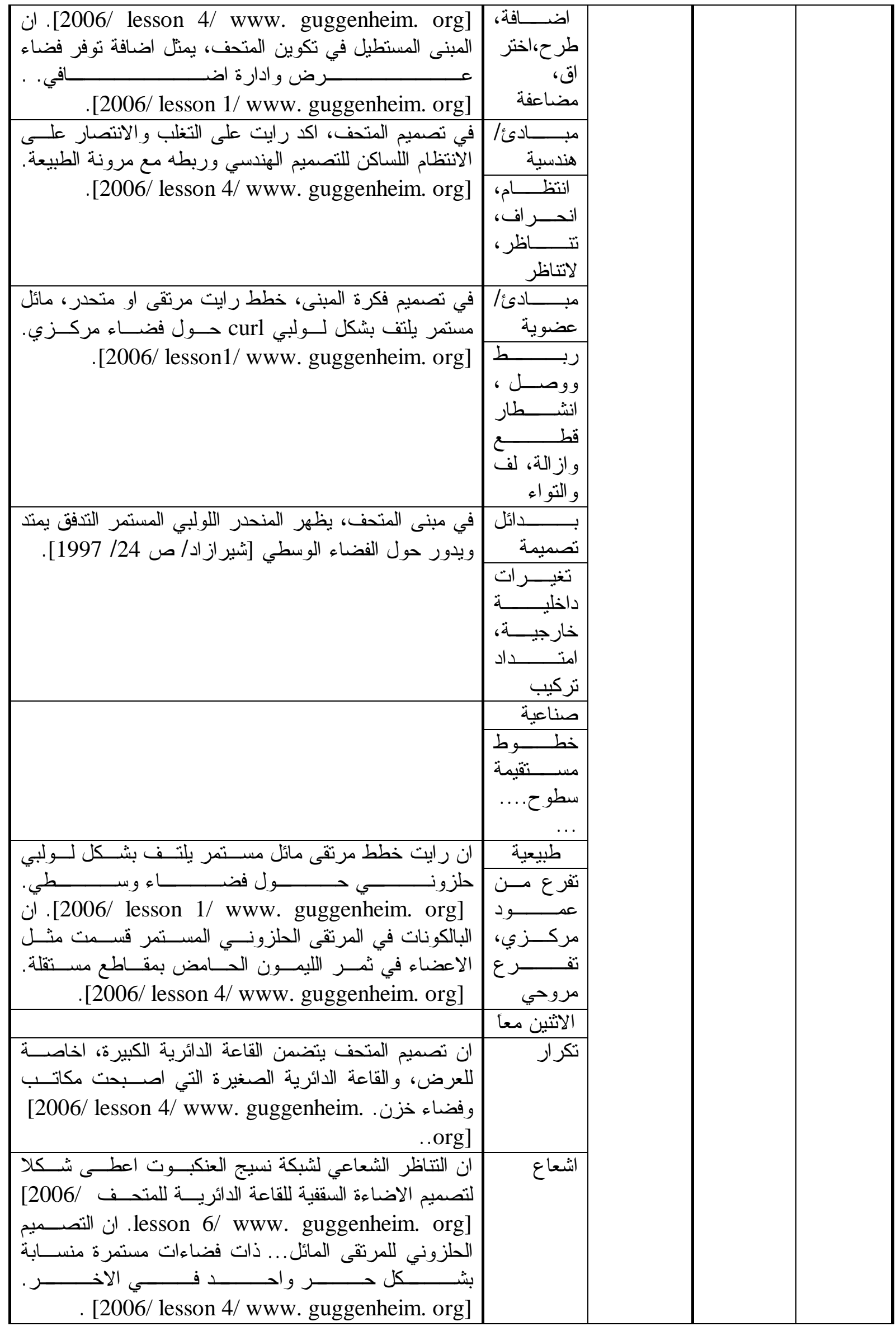


الثيخ : وصف عنصر الهيئة في التكوين المعماري وصيغ توليد انماطه في نتاجات المعمار رايت

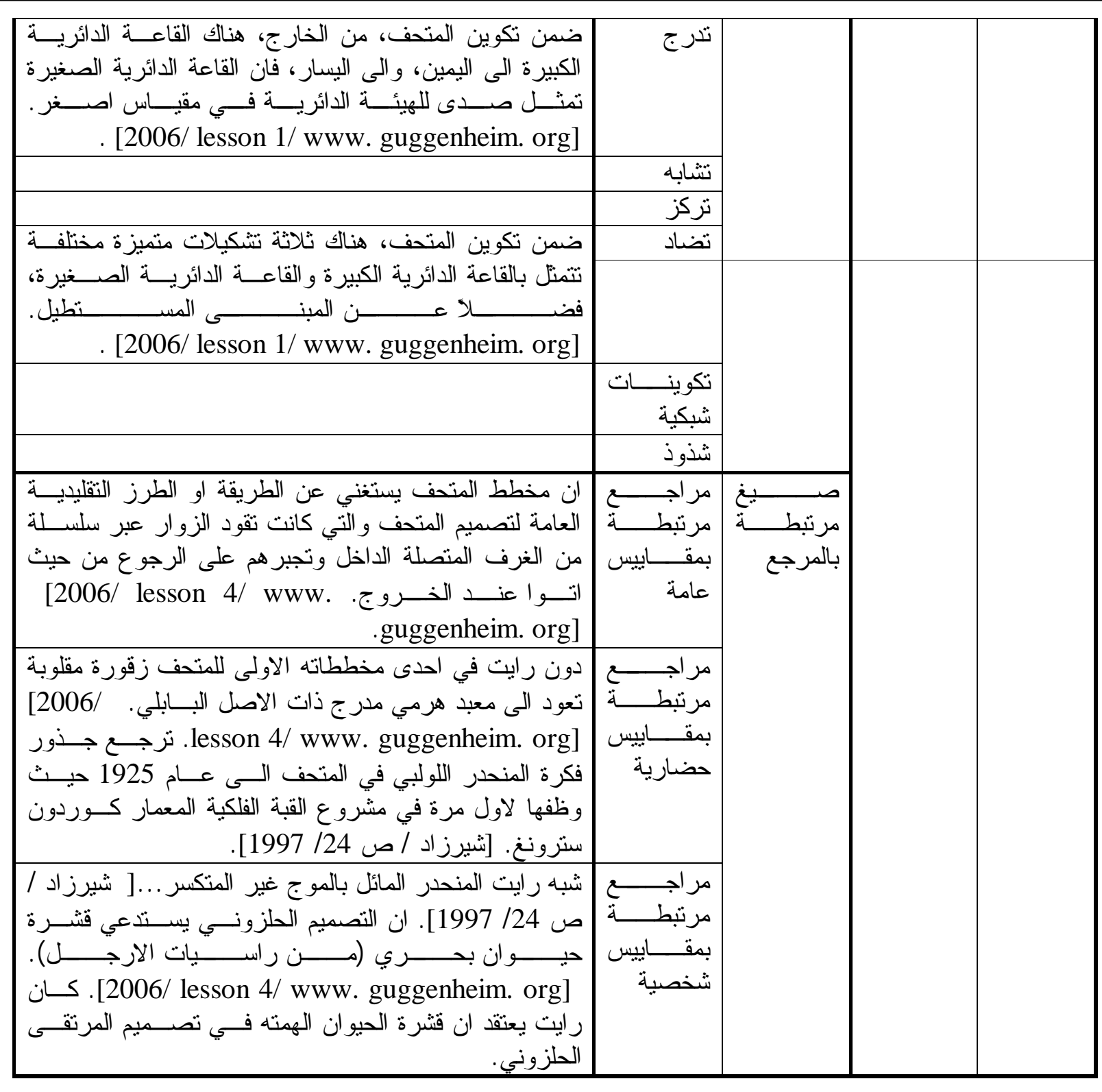

6

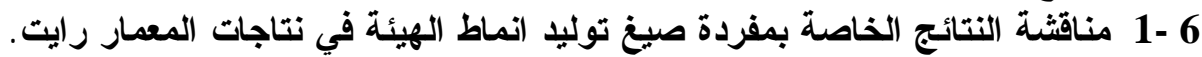

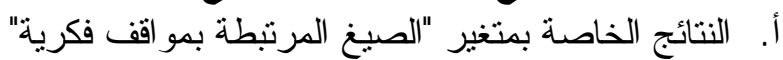

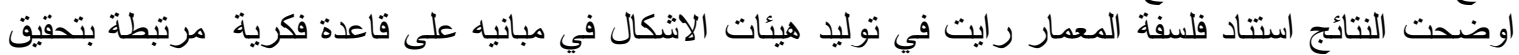

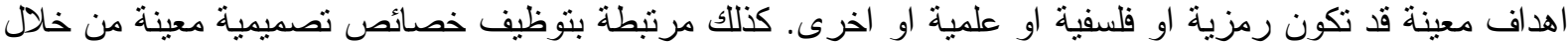
الاندماج الكامل ما بين هيئة الثنكل وخصائص موقعه، واخير آ مرنبطة بنوعية المر اجع بحيث يبدو الناتج النهائي للهيئــة

ب. النتائج الخاصة بمتغير "الصيخ المرتبطة بخصائص الهيئة ، اوضحت النتائج نركيز المعمار رايت في توليد لئنية هيئات الاشكال على كل من الخصائص الكمية و اللاكمية وكما يلي:

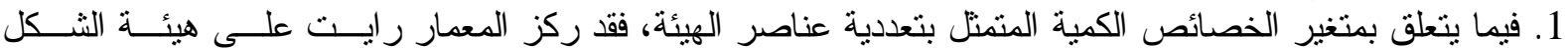
التجميعي (هيئة منعددة) اكثز من هيئة الثكل الثنئة الثنفرد.

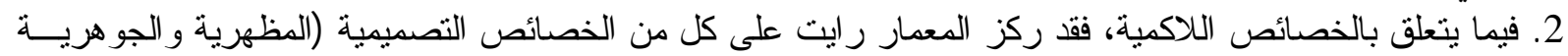

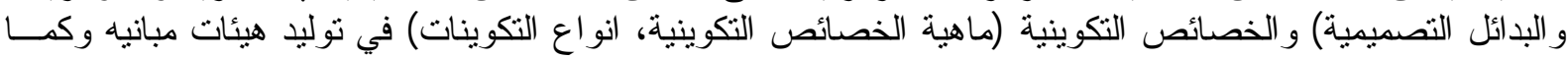


2 -1 - 1- فيما يتعلق بالخصائص التصميمية المظهرية، فقد اكد المعمار رايت على توظيف كل من عناصر هيئة الثــــل

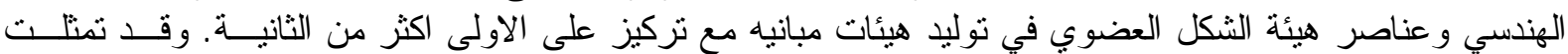

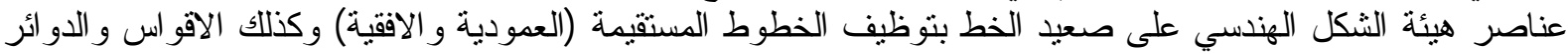

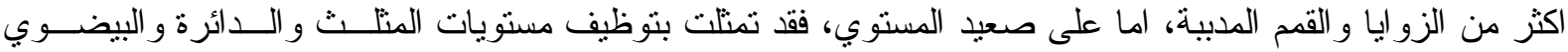

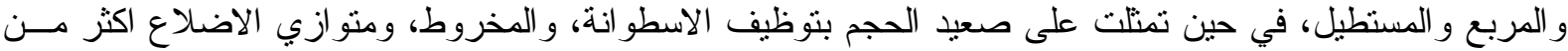

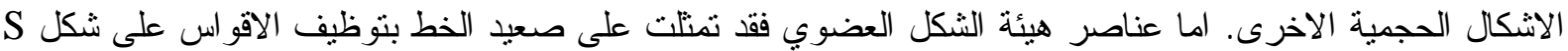

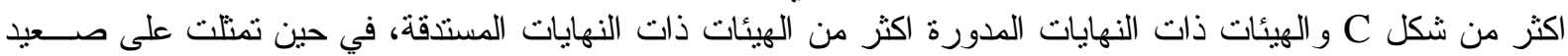
المستوي و الحجم بتوظيف هيئات الاشكال الحلزونية.

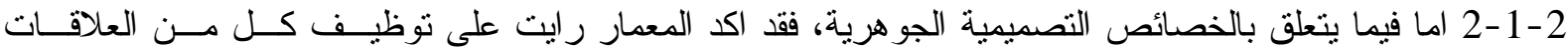

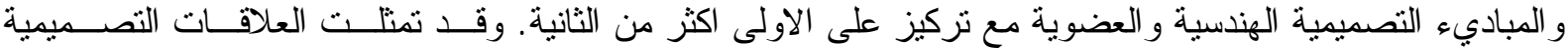

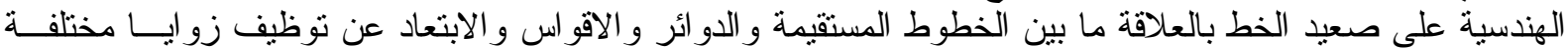

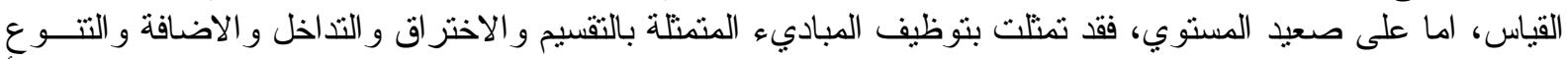

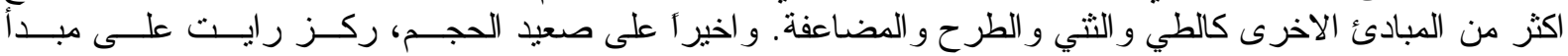

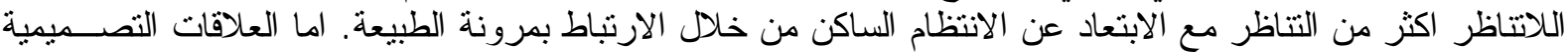

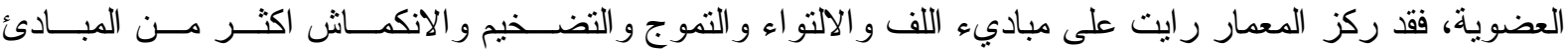
التصميمية الاخرى في توليد هيئات مبانيه. 2 -1 -3 و اخير الركز المعمار رايت على نوظيف بعض البدائل التصميمية لنطوير الهيئة وقد تمثلت بالامتداد و التزكيب

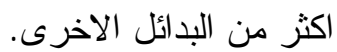
2-2 2-2 الخصائص التكوينية

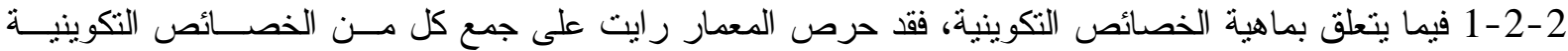

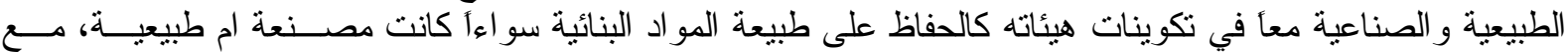

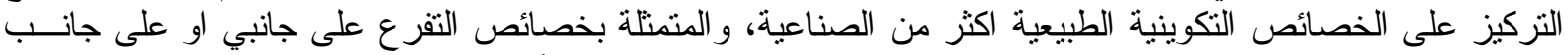

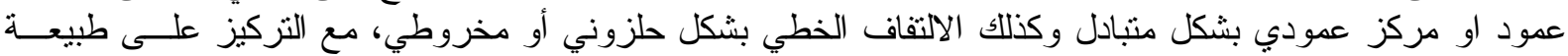

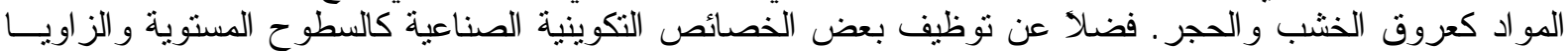
القائمة و الاسطونات وطبيعة المو اد الصناعية كالخرسانة المسلحة اكثر من طريقة تجميع الاجز اء كالالية الصناعنة الصناعية.

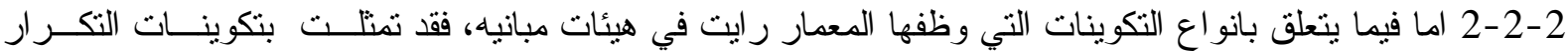

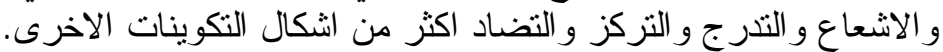

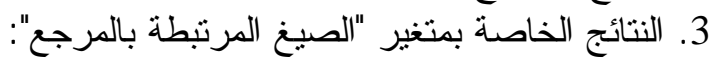

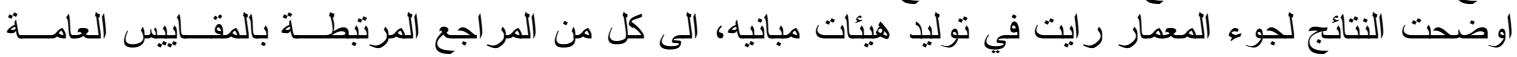

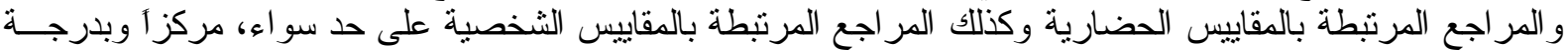

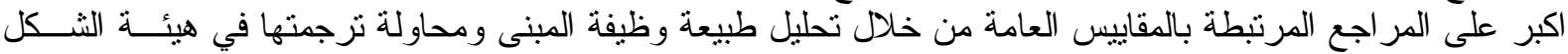

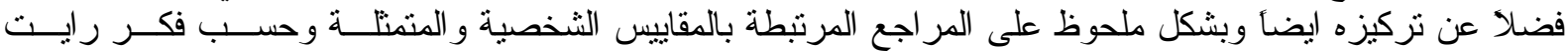

2-6 الاستنتاجات النهائية الخاصة بوصف عنصر الهيئة في التكوين المعماري وصيغ توليد انماطه في عمارة رايت

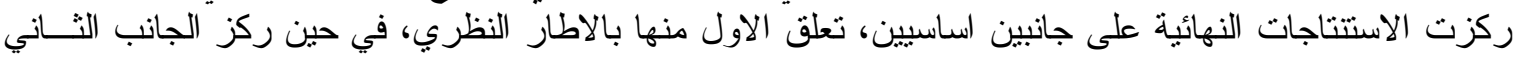
على الاستتناجات الخاصة بالنطبيق.

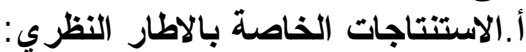

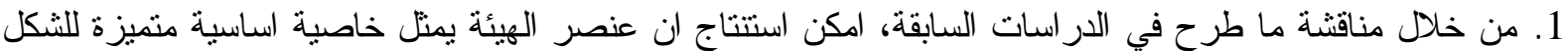

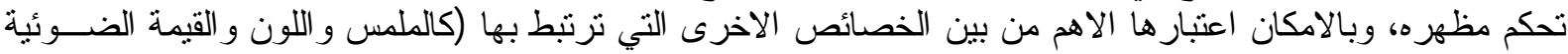

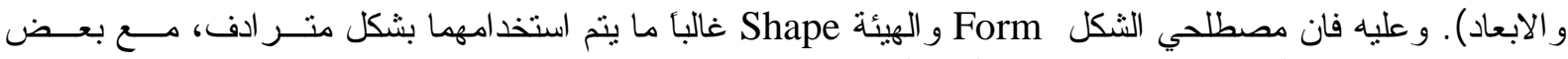

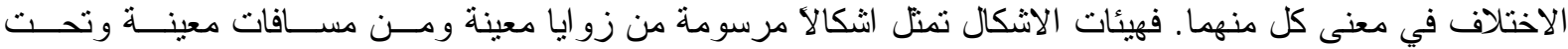

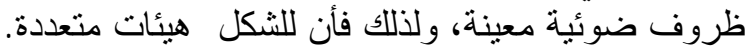

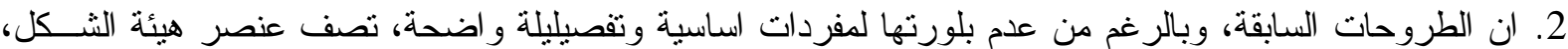

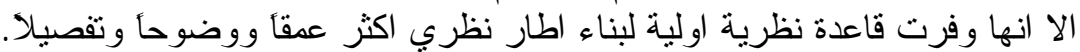

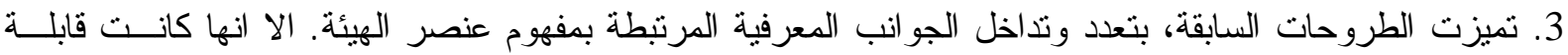

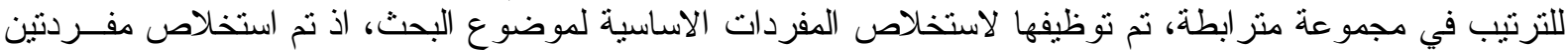

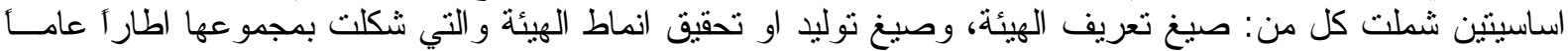


ب.الاستنتاجات الخاصة بالتطبيق:

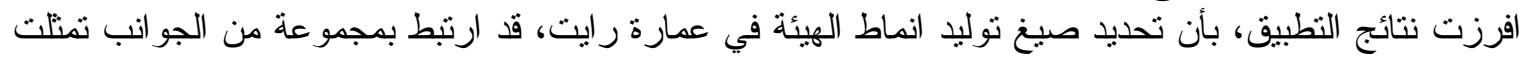

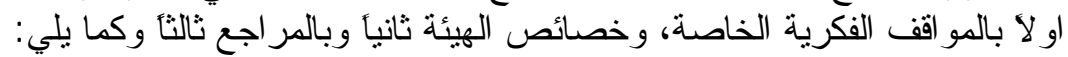

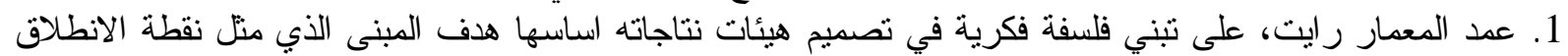

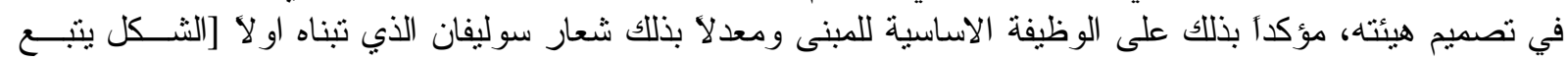

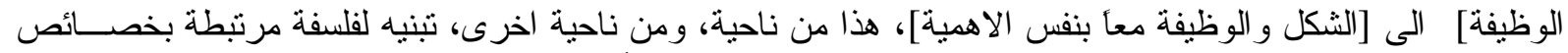

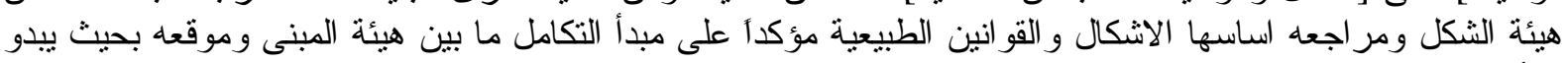

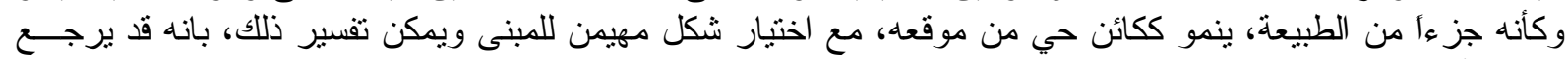

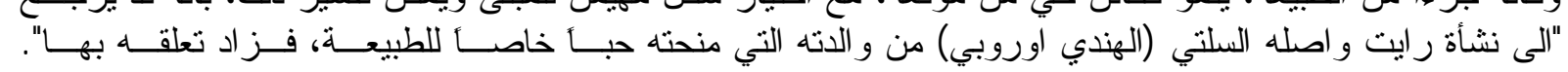
[2001/ P. 18/ Pearson]

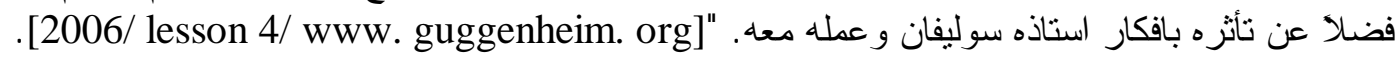

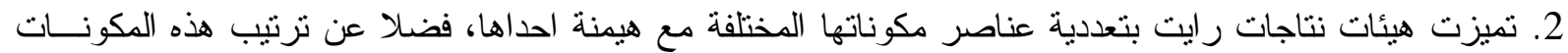

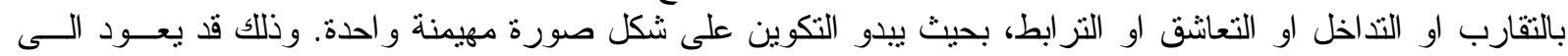

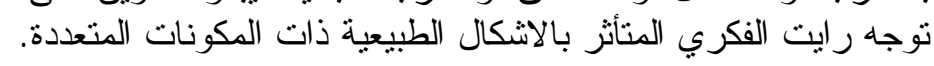

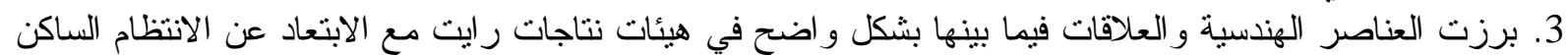

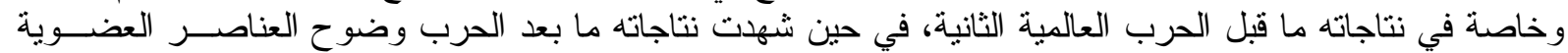

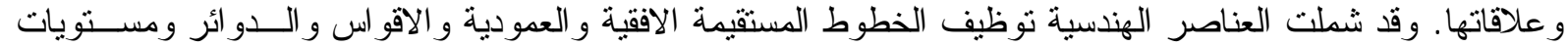

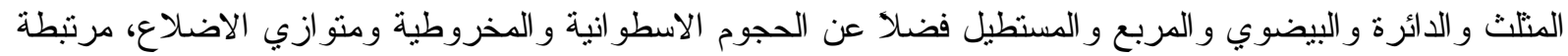

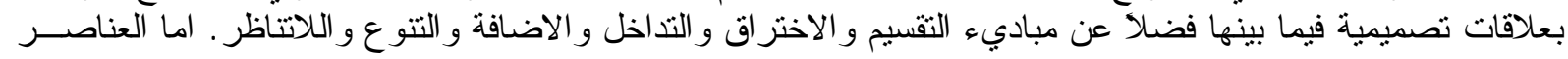

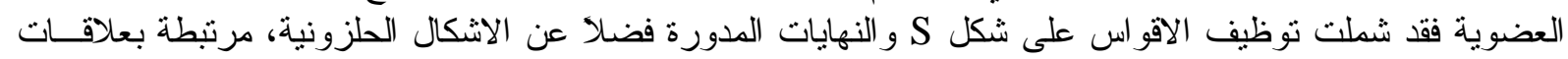

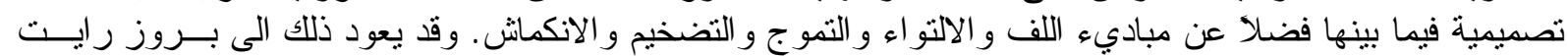

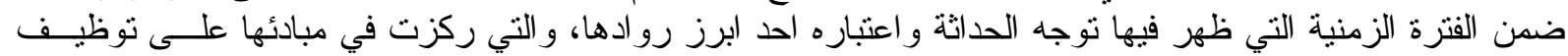

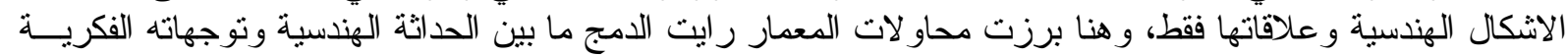

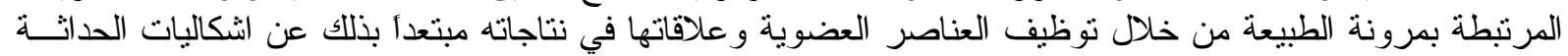

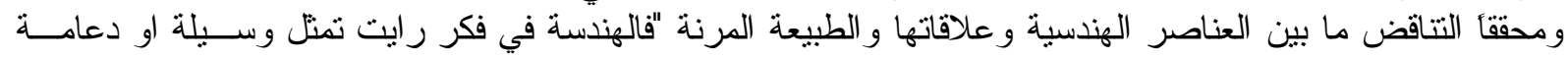

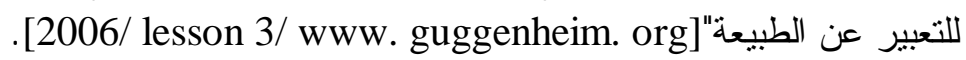

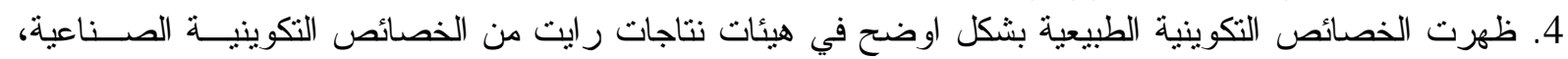

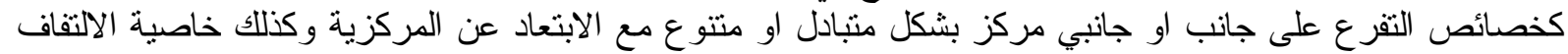

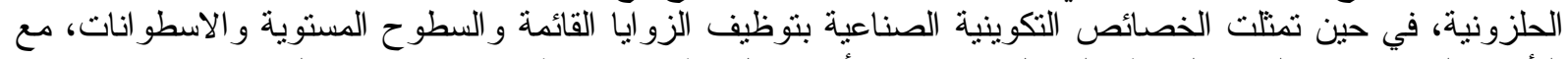

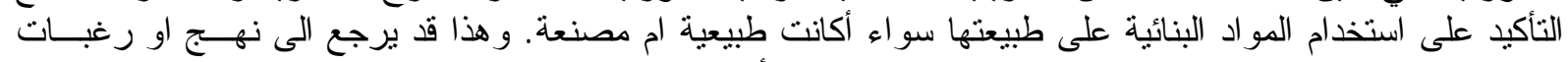

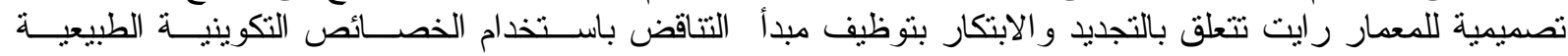
و الصناعية جنباً الى جنب رئب عند توليد بليد هيئة النتاج.

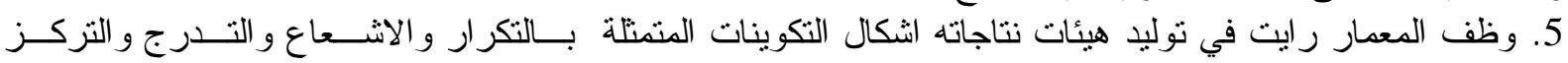
و التضاد، مستلهماً ذلك من أثكال التكوينات الطبيعية.

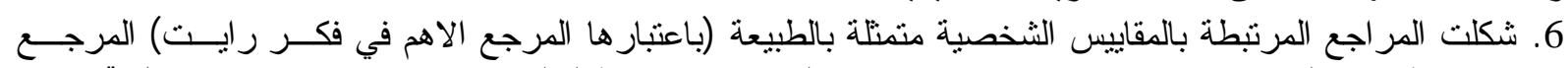

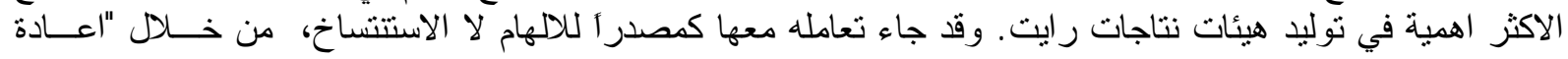

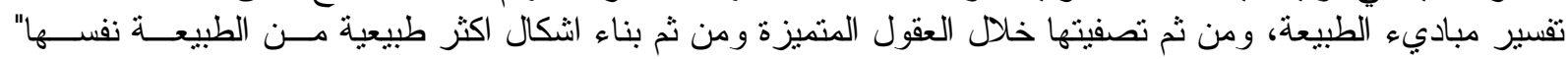
و2006/ essay1/ Elman]

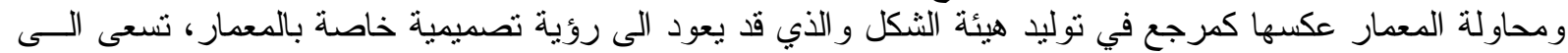

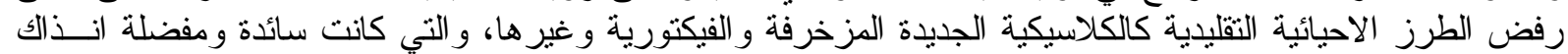
من قبل العديد من المعماريين. 


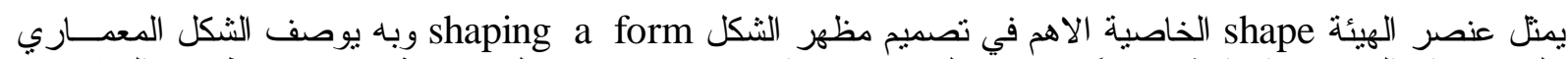

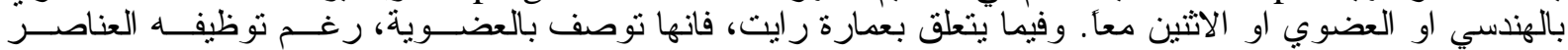

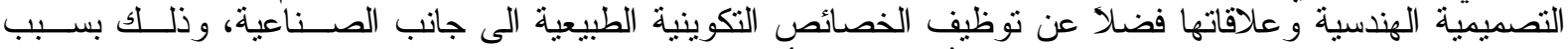

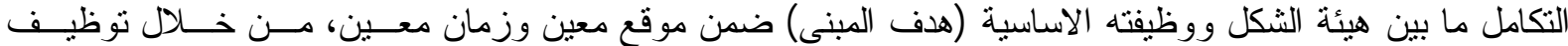

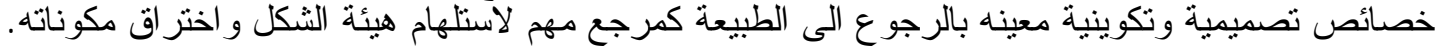
4-6 التوصيات

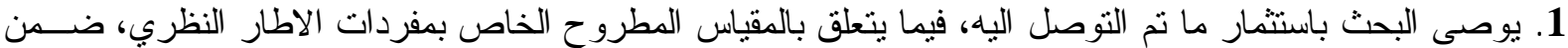

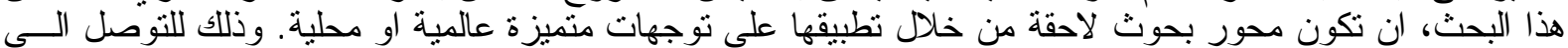

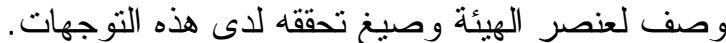
2. يوصي البحث بالاستفادة من القاعدة المعلوماتية التي وردت فيه لحل مشكلات الو اقع المعماري الاكاديمي و العملي.

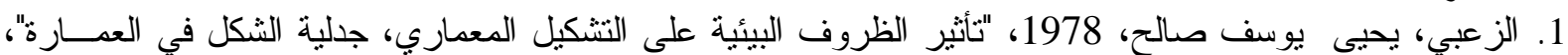

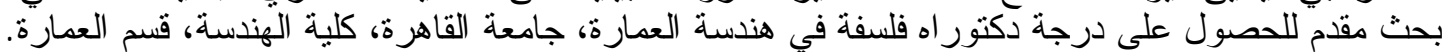

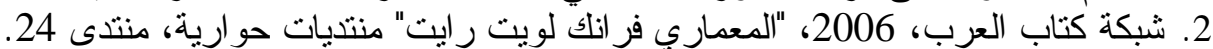
http://university,Arabs book.com/forum 24/thread 8562.htm.

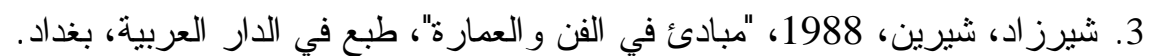

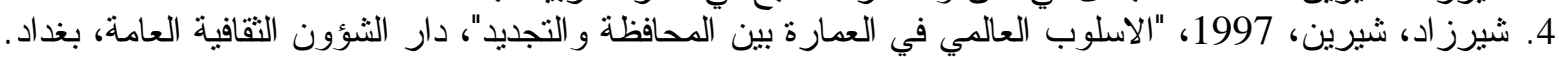

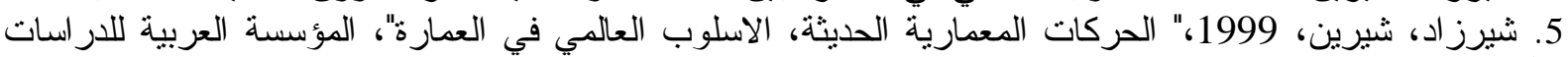

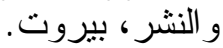

\section{References}

1. ALLIANCE FOR THE ARTS, Solomon R.Guggenheim Museum Manhattan, 2006,"Lesson 1 to 7", New York City's Cultural guide for kids. Htm. http://www. Guggenheim.org/.

2. Ching Francis D. K., 1996. "Architecture, Form, Space and Order, $2^{\text {nd }}$ Edition, Nostrand Reinhold. usa.

3. E lman, Kimberly, 2006, "Framk Lioyd wright and the principles of organic Architecture." Legacy Essay. http:// www. Pds. Org/ flw/ Legacy/ essay 1 htm1.

4.FormMain, 2006, "The Elements of Art, Shape". Inc /All rights reserved. Privacy policyTerms of service Copy right/ ip policy.

www.brigantine.atlnet.org.

5.Graves, Maitland, 1951, "The Art of Color and Design", Mcgraw Hill, Book Company.

6.Jirousek, Charlotte, 2003, "Art Design and Visual Thinking, Form, shape and Space", An Interactive Text book, New York State College of Human Ecology Cornell university.

7.Kimberly and Albrecht powell, 2002, "Falling water- mill run, Pennsylvania, The masterpiece of Architect frank lioyd wright".

http://pittsburgh about. Com/ Library fallingwater.htm

8. Kostof, Spiro, 1985, "A history of Architecture Settings and Rituals, New York, oxford university press.

9. Malnar, Vodvarka, 1992, "The interior Dimension", by John Wiley and Sons, Inc. Published simultaneously in Canada, Printed in U.S.A.

10. Mccumber, D. Michael, oct. 7,2005, "Frank Lioyd Wright's Falling water, the Kaufmann Conservation on Bear Run. www.Fay - west. Com.

11.Pearson, David, 2001, "New Organic Architecture, The Breaking wave". California press. 12.sharp, Denis, 1972, "A Visual History of Twentieth Century Architecture, "New York Graphie Society Ltd, U. S. A.

13. Thomas, Deborah, 2003, "Elements of Art and Principles of Design, Shape".

14. Wikipedia, the free encyclopedia August 2001 issue, "Falling Water" en. Wikipedia. Org/ Wiki/ Fallingwater.

15. Wong, Wucius, 1993, "Principles of Form And Design" by John Wiley and Sons, Inc, New York, U.S.A.

تـ احر ائ البحث في كلبة الهندسة ـ حامعة المو صل 